\title{
A high prevalence of NCD multimorbidity in South African Adolescents and Youth Living with HIV: Implications for Integrated Prevention
}

Monika Kamkuemah ( $\nabla$ monika.kamkuemah@gmail.com )

University of Cape Town School of Public Health and Family Medicine https://orcid.org/0000-00027603-2792

\section{Blessings Gausi}

Tolu Oni

\section{Research}

Keywords: Adolescents, HIV, Non-communicable diseases, Mental health, Risk factors, Prevention, Epidemiology, Multimorbidity

Posted Date: February 11th, 2021

DOl: https://doi.org/10.21203/rs.3.rs-75447/v2

License: (c) (i) This work is licensed under a Creative Commons Attribution 4.0 International License. Read Full License 


\section{Abstract}

Background: Adolescents and youth living with HIV (AYLHIV) face an elevated NCD risk resulting from HIV, psychosocial challenges and the complications of antiretroviral therapy (ART).

Methods: We conducted a cross-sectional study in six primary care facilities to investigate the prevalence of common NCDs and risk factors among AYLHIV in Cape Town, South Africa between March 2019 and January 2020. We collected socio-demographic information, ascertained behaviours and knowledge and screened for pre-existent and previously unidentified NCDs and risk factors in adolescents and youth enrolled for primary HIV care. Characteristics between sexes and age groups were compared using parametric or non-parametric statistical tests.

Results: Three out of four participants were female, and the median age was 20.5 years (IQR 18.9- 22.9). More than a quarter were not in education, employment or training (NEET) and $44 \%$ were multidimensionally poor. Our results show an existent burden of hypertension (5\%) and central obesity $(37 \%)$ as well as high levels of depression (43\%) and psychological distress symptoms (44\%). AYLHIV further self-reported high levels of household food insecurity (70\%), low fruit and vegetable consumption, high fast-food and sugar-sweetened beverage intake, low nutritional knowledge and insufficient physical activity. Beyond the NCD risk attributable to HIV and ART, these multiple risk factors further increase NCD risk.

Conclusions: Our findings highlight the importance of integrated prevention with NCD risk screening as part of HIV care for AYLHIV and the need for early intervention on social, environmental and economic determinants of NCDs targeting adolescents and youth.

\section{Background}

Globally, non-communicable diseases (NCDs) are the leading cause of disability and premature mortality accounting for $71 \%$ of deaths worldwide and $80.6 \%$ of years lived with disability (YLD) in $2016[1,2]$. NCDs are rising globally and affect low- and middle-income countries (LMICs) disproportionately, with more than three-quarters of NCD deaths occurring in LMICs [3]. Of note, unhealthy diets and physical inactivity which are significantly associated with obesity, diabetes, cardiovascular disease and cancers are rising globally, particularly in LMICs $[2,4,5]$. 000

In 2017, the burden of NCDs in sub-Saharan Africa (SSA) was higher than the global average, almost equivalent to the total burden associated with communicable, maternal, neonatal, and nutritional (CMNN) diseases [6], with rapid urbanization contributing to unhealthy diets and sedentary behaviour, especially amongst the poor residing in urban settings [7]. Epidemiological analyses from 1980-2014 show that age-standardized average body mass index (BMI) and diabetes prevalence have increased steadily across Africa, at least as steeply as the global average [8]. 
In South Africa, an upper-middle-income country, the prevalence of NCDs and NCD risk factors has increased over the last two decades. South Africa is said to be undergoing rapid epidemiological transition with a quadruple burden of disease [9]. To illustrate, the prevalence of overweight and obesity among adult South African women increased from $56 \%$ to $68 \%$ between 1998 and 2016 [10] and 51\% of deaths were attributable to NCDs in 2016 [11]. One in three South African adults has hypertension, $16.2 \%$ smoke daily [12], $18.3 \%$ engage in heavy episodic drinking [13] and more than $30 \%$ of females and a quarter of males reported experiencing psychological distress [12].

Importantly, this rising NCD risk is also occurring in children and adolescents [14]. Adolescence is a critical period of both opportunity and risk accompanied by rapid physical and psychological development that sets the foundation for adult health $[15,16]$. Many NCD-related risk factors are initiated or reinforced during adolescence, which makes it a critical period for intervention to prevent future disease. Despite knowledge that many of these diseases and risk factors start in adolescence, there has been little focus on NCD prevention in this age group. South Africa has the highest prevalence of childhood and adolescent overweight and obesity in sub-Saharan Africa ( $19 \%$ of boys and $26 \%$ of girls under 20 years) rivalling that of many high-income countries [17]. Overweight and obesity rates have increased steadily especially amongst adolescents residing in urban settings [18] with over $40 \%$ of young people reporting insufficient levels of physical activity, and 30\% spent more than three hours per day sedentary [14].

NCDs in LMICs are occurring in the context of persisting high infectious disease prevalence [19]. In South Africa, this is occurring alongside a persisting high burden of HIV/AIDS and tuberculosis [20]. South Africa has the largest HIV epidemic and antiretroviral treatment (ART) programme in the world, with 7.5 million people documented to be living with HIV in 2019 and 5.2 million on ART [21]. Of note, this includes adolescents and youth, with South Africa reporting the highest burden of adolescent HIV globally [22]. Of the 1.6 million adolescents reported to be living with HIV worldwide in 2018, 19\% are South African [22].

HIV and ART are associated with several NCDs. Evidence on increased prevalence of NCD comorbidities has been documented in adults living with HIV (PLHIV) [23], with an excess burden of NCD risk factors in PLHIV compared to the general population [24]: $49 \%$ are insufficiently physically active [25], $40-70 \%$ are current smokers $[26,27]$ and $37-66 \%$ are current drinkers [28,29]. In South Africa, almost half of adult patients attending HIV clinics in Cape Town engaged in hazardous alcohol use, and $15 \%$ had problematic drug use [30].

Adolescents and Youth living with HIV (AYLHIV) face elevated health risks [31,32] with similar comorbidity patterns to adults identified in paediatric and adolescent cohorts worldwide as a consequence of HIV and long term ART but not necessarily in the context of rapid epidemiological transition Of note, given that AYLHIV routinely access care, and are potentially additionally vulnerable to NCDs, there is an opportunity for early intervention to identify risk factors and prevent other comorbidities. Where these services have been integrated with HIV care among adolescents and youth, such services have largely focused on reproductive health $[33,34]$ with little to no focus on NCDs. 
A previous study explored this missed opportunity in Cape Town reviewing clinical folders of AYLHIV to identify the extent to which NCD risk factor screening is routinely implemented. This study demonstrated that despite evidence of existing NCD comorbidity and risk factors in AYLHIV, there was limited integration of NCD screening and health promotion in adolescent and youth HIV healthcare services [35]. This raises questions about the true prevalence of NCD multimorbidity in this population group needed to inform service delivery.

Of note, while previous studies of AYLHIV in SSA have described risks associated with sexual behaviour $[36,37]$ tobacco and substance use [38,39], there is overall data paucity on the breadth of NCDs and associated risk factors in this population group in SSA. With the first cohorts of AYLHIV now entering adulthood and the move towards more comprehensive health services aimed at improving the quality of life of PLHIV, questions remain on the prevalence of NCD comorbidity and NCD risk factors in AYLHIV and the best way to ensure holistic adolescent health and well-being.

We thus aimed to assess the prevalence of the most commonly occurring NCDs and risk factors that could benefit from early intervention, with a focus on cardiometabolic, respiratory and mental health conditions and risk factors in AYLHIV accessing primary health care in urban Cape Town.

\section{Methods}

\section{Study Setting and Population}

We conducted a cross-sectional study of AYLHIV aged 15 - 24 years attending primary care health facilities in Cape Town. Cape Town is the second biggest metropolitan city in South Africa with an estimated population of 4.2 million people [40]. In 2016, adolescents and youth aged 15 - 24 years comprised $16.3 \%$ of the population in the Western Cape province, within which Cape Town is located [10]. NCDs and HIV are ranked amongst the top causes of premature deaths in the City of Cape Town [41], with the top five causes of death in 2016 ranked as diabetes mellitus, HIV, ischaemic heart diseases, cerebrovascular diseases and TB [42].

The City of Cape Town delivers primary health care through four legislated substructures: Khayelitsha / Eastern, Mitchells Plain / Klipfontein, Western / Southern and Northern / Tygerberg [41]. Recruitment and data collection took place at six public sector HIV clinics, with 1 - 3 clinics selected within each of the four sub-structures (Figure 1). These facilities serve patients living in peri-urban, high-density, low-income townships, collectively known as the Cape Flats

\section{Study Design and Sampling}

The sample size was determined using prevalence estimates for obesity (for which data are readily available) from the South African National Health and Nutrition Examination Survey 2012 for the 15 - 24 years age group [12]. The confidence level was set at $95 \%$, with a $5 \%$ degree of precision, and an obesity prevalence of $5.6 \%$, yielding a minimum required sample size of 86 , adjusted for a $5 \%$ non-response rate. 
Prior to data collection, we conducted stakeholder engagement, liaising with facility managers and youth healthcare providers to optimise recruitment strategies for each clinic. We previously described the method used to estimate the number of AYLHIV accessing care at each facility [35]. Details of the study were shared at each AYLHIV clinic and a convenience sampling approach was used. Participant recruitment commenced in March 2019 after ethical clearance was obtained from the University of Cape Town Faculty of Health Sciences Human Research Ethics Committee (HREC ref no: 520/2017) and approval from Provincial and Local Government Departments of Health. Parents or legal guardians gave permission for their children to participate in the study, and participants provided informed assent (or consent if 18 years or older). Recruitment and study procedures were then conducted after gaining written informed consent and assent at six facilities until January 2020 (Figure 1). Participants received reimbursement for transport costs.

Figure 1: Participant Recruitment and enrolment at respective facilities

\section{Study Procedures}

\section{Socio-demographic characteristics}

Adolescence: can be categorized into three primary developmental stages; early adolescence (10 - 14 years), middle adolescence (15 - 17 years), and late adolescence / young adulthood (18 - 24 years) [43]. For the purposes of this study, we categorized participants into four age groups in line with these stages, further sub-dividing the oldest age group as follows: 15 - 17, 18 - 19, 20 - 21 and 22 - 24 years.

Deprivation: Questions on socioeconomic status were derived from the 2011 South African Census [44] and deprivation assessed using the Youth Multidimensional Poverty Index (YMPI) comprising eleven weighted indicators in five dimensions: educational attainment, general health and functioning, living environment, household assets and employment [45]. An individual was defined as being multidimensionally poor - MPI poor- if they were deprived in a third or more of the weighted indicators, with a composite score $\geq 33.3 \%[45]$.

Food insecurity. was measured using the Household Food Insecurity Access Scale (HFIAS) score [46]. Participants were categorized as living in food secure, mildly-, moderately-, or severely food insecure households according to the HFIAS protocol [47].

\section{Behaviour and Knowledge}

Physical activity: was assessed using the International Physical Activity Questionnaire (IPAQ) [48], validated in youth and adults in South Africa [49]. We used the Ainsworth et al. scoring algorithms to derive an average metabolic equivalent of task (MET) intensity level score for each type of physical activity: vigorous, moderate, walking and cycling [50]. Physical activity levels were further categorized according to the IPAQ scoring protocol into low, moderate and high [51]. Insufficient physical activity was defined as a score below 600 MET minutes/week [52]. The presence or absence of sedentary behaviour 
was dichotomized as spending three or more hours per day watching television, playing computer games, talking with friends or other sitting activities [53].

Dietary intake: was assessed using a 23-item food frequency questionnaire (FFQ) adapted from the Health Behaviour in School-aged Children Survey [54] validated for use in adolescents [55]. We estimated the proportion who ate fresh fruits and vegetables daily (once or more than once a day in the previous week) and frequently (on four or more days in the previous week) and the proportion of respondents who reported daily consumption of sugar-sweetened beverages (SSB), deep-fried foods, fast foods, salty snacks, and processed meats. Skipping breakfast was defined as eating breakfast on 0 - 2 days/week; semi-skipping, 3 - 4 days/week and not skipping, 5 - 7 days/week.

Nutritional knowledge: was assessed using a revised General Nutrition Knowledge Questionnaire (GNKQ$\mathrm{R}$ ), validated for use in young people [56]. A nutritional knowledge score was generated by totalling correct answers in four nutrition domains. The maximum possible score was $88 ; 18$ for questions on "dietary recommendations", 36 for questions on food groups, 13 for "healthy food choices" and 21 for "associations between diet and disease". No norms exist to determine an adequate nutrition knowledge score [57]. Hence we computed the average nutrition knowledge score and compared the mean scores for each of the nutrition domains by gender and age groups comparable to a previous study of South African adults [58]. The percentage of respondents who answered the questions correctly in each domain was calculated.

\section{Comorbidities}

Respiratory disease: was defined as self-reported pre-existing diagnosis of asthma, tuberculosis, bronchitis, or other lung disease. Experiencing any of the following symptoms in the preceding three months was characterized as presence of respiratory symptoms: prolonged cough with sputum for more than two weeks, chest tightness, shortness of breath, difficulty breathing; or having an abnormal peak flow reading (using a hand-held peak flow meter in accordance with standard guidelines [59]).

Diabetes: was defined either as i) a pre-existing self-reported diagnosis; ii) a random blood glucose reading of $>7 \mathrm{mmol} / \mathrm{l}$ (using a point-of-care (POC) glucometer with reactive test-strips (Glucocheck Evolve ${ }^{\circledR}$ Homemed Pty) and having a family history of diabetes; or iii) a random blood glucose reading of $>7 \mathrm{mmol} / \mathrm{l}$ and experiencing diabetes-related symptoms over the past three months: frequent urination, increased thirst, unexplained weight loss of more than $1.5 \mathrm{~kg}$ in the last month, unexplained fatigue, blurry vision.

Blood pressure: Sitting blood pressure (BP) was measured using a Rossmax automatic blood pressure monitor (Rossmax (Shanghai) Incorporation Ltd) using the South African hypertension practice guidelines [60].

Depression and psychological distress: were defined using symptom screening questions from the 10item Centre for Epidemiological Studies Short Depression Scale (CESD-10) $[61,62]$ and the Kessler 
Psychological Distress Scale (K10) [63]. Both tools have been validated in South African PLHIV [64,65] and in adolescents and young adults [66]. Depression was defined as a binary indicator using a cut-off score of 10 or more on the CESD-10 scale [61] and the likelihood of psychological distress was categorized according to the K10 score: K10 < 20: mentally well; K10 20 - 24: likely to have mild psychological distress; K10 25 - 29: likely to have moderate psychological distress; K10 30 - 50: likely to have severe psychological distress [67].

Overweight and obesity: Height, weight and waist circumference (WC) were measured according to the WHO STEPS Protocol [68]. The abdominal obesity cut-off point for a high WC was $\geq 102 \mathrm{~cm}$ in males and $\geq 88 \mathrm{~cm}$ in females and a waist-hip ratio $($ WHR) $>0.85$ for females and $>0.90$ for males [68]. Waistto-hip ratio was calculated by dividing the WC by the hip circumference in centimeters rounded to two decimal places. A threshold value of 0.5 for the waist-to-height ratio (WHtR) was used as a measure of central obesity, calculated by dividing the WC by the height in $\mathrm{cm}[69]$.

\section{Statistical Analysis}

Graphical data exploration and Shapiro-Wilk's tests were used to test for normality of variables. All data were analysed and stratified by sex and age. Demographic and socioeconomic variables were described using summary statistics (frequencies, percentages, median and interquartile range (IQR)).

Characteristics between sexes and age groups were compared using Pearson's $\chi 2$ and Fisher's exact tests for categorical measures. The Wilcoxon-Mann-Whitney test was used to compare medians between groups and the Kruskal-Wallis test was used for comparing continuous measures in more than two groups. All tests of significance were two-tailed and performed at the $5 \%$ significance level. Data analysis was conducted using Stata version 14.0 (StataCorp, College Station, Texas, USA).

\section{Results}

\section{Socio-demographic baseline characteristics}

A total of 176 adolescents and youth were recruited and invited to participate, of which 92 were successfully interviewed. The majority (76\%) were female and the median age was 20.5 years (IQR 18.922.9)(See Table 1). The majority lived with a biological parent or a relative. More than a quarter of female respondents reported ever being pregnant. Overall, $44 \%$ of participants can be considered multidimensionally poor as they were deprived in a third or more of the five dimensions of MPI indicators (Table 1). More than half were living-environment deprived with over a third living in informal housing, $28 \%$ living in households that do not use electricity, gas or solar power for heating and $17 \%$ living in households without piped water available on site. Almost a quarter of respondents were deprived in educational attainment and 39\% were economically deprived: $27 \%$ were neither in education, employment or training (NEET) , while 15\% were living in households with no employed adults of working age and $3 \%$ were deprived in both economic indicators. The majority of participants were living in food insecure households with $38 \%$ considered as severely food insecure: either having to cut back on meal size, number of meals or going a whole day and night without eating in the last month. 


\section{Behaviour and Knowledge}

\section{Physical activity}

Overall, a third of respondents had insufficient levels of weekly physical activity, $41 \%$ had moderate levels and $27 \%$ had high levels of physical activity. A greater proportion of males had high levels of physical activity compared to females ( $44 \%$ vs $22 \%$ respectively). The total median MET-minutes of physical activity a week including active transport) was higher for males compared to females, but this was not statistically significant (Table 2). The youngest age group reported the highest rates of vigorous-intensity physical activity (Table 3). Over two-thirds of all participants ( $84 \%$ males; $67 \%$ females) reported using active transport in the preceding week (mostly walking to school/work for at least ten minutes continuously). Almost half of respondents spent more than three hours sedentary during a typical day, with no difference in sedentary behaviour by gender.

\section{Dietary intake}

Overall, less than a third of respondents ate fruits and wholegrains daily (Table 2) with significantly more males reporting eating fruit frequently compared to females. More than half ate vegetables daily (either dark green, orange or other vegetables) and younger adolescents had the lowest daily consumption of fruits, vegetables and wholegrains compared to older age groups. A third of respondents had a high dietary intake of sugar; either reporting drinking SSB daily or eating sweets and cakes daily. SSB consumption was similar across gender and age groups. Older adolescents aged 18-19 years had the highest daily consumption of deep-fried and fast foods compared to other age groups (Table 3 ).

Meals eaten outside the home

Two-thirds of respondents ate at least one meal that was prepared outside the home in the previous week. Those who ate food prepared outside the home, ate a median of two take-away or sit-down meals in the past week (IQR 2-4 meals). Males had a larger variability in meals consumed that were prepared outside the home compared to females.

\section{Breakfast}

Over half of participants reported eating breakfast on at least five days in the previous week, one in five participants ate breakfast on 3-4 days in the week and one in five reported skipping breakfast or eating breakfast on less than two days in the previous week. Skipping breakfast did not differ significantly by gender or age.

\section{Nutrition Knowledge}

Overall, the mean GNKQ-R score achieved by adolescents was 33 out of a total of 88 points (37.5\%). Knowledge of dietary recommendations was the highest-scoring domain with an average of $44 \%$ while 
knowledge of healthy food choices was the lowest-scoring domain at 32\% average score. There were no significant differences in nutrition knowledge amongst adolescents by sex and age group (Figure 2).

\section{Comorbidities and symptom screening}

\section{Respiratory diseases and symptoms}

TB was the most common pre-existing comorbidity reported by $23 \%$ of participants. Less than $5 \%$ had a previous diagnosis of asthma (Table 4). Eleven participants (12\%; 95\% Cl: $6.3-21 \%)$ reported experiencing one or more respiratory symptoms over the past three months. Peak flow measurement was performed for five participants who reported respiratory symptoms but had no known asthma diagnosis. All the measurements were within the normal - green- peak flow zone.

\section{Diabetes}

Only one participant (who also reported diabetes symptoms) reported a previous diabetes diagnosis. A quarter of participants $(95 \% \mathrm{Cl}: 16-35 \%)$ reported experiencing one or more diabetes-related symptoms over the past three months (Table 4). Younger age groups (15-17 years and 18-19 years) reported more diabetes-related symptoms compared to older age groups (Table 5). Overall, $27 \%$ reported a family history of diabetes (95\% Cl: $18-37 \%)$. Of those with reported symptoms or a reported family history of diabetes who had their blood glucose measured $(n=31)$, none had a measured random blood glucose of more than $7 \mathrm{mmol} / \mathrm{L}$.

\section{Blood Pressure}

Overall, $20 \%$ had an elevated blood pressure and $5 \%$ had hypertension. Figure 4 shows that the prevalence of elevated blood pressure and hypertension was higher in males compared to females ( $p=$ 0.0367 ). Systolic and diastolic blood pressure showed an increasing trend with age (Table 7). The median age of those with elevated blood pressure or hypertension was 21.2 (IQR 18.8 - 22.7) years, similar to those with normal blood pressure (median 20.2, IQR: 19.0 - 22.8 years). Of those with elevated blood pressure or hypertension,11 (35\%) were overweight or had obesity and 2 (6\%) reported a previous diagnosis of hypertension (data not shown in tables).

\section{Depression and psychological distress}

More than two-fifths of participants reported experiencing significant depression in the past week (95\% Cl: $32-54 \%)$. Female participants were significantly more likely to report depressive symptoms compared to males (Table 4 and Figure 3). Of those with significant depression, 6/35 (17\%) reported a previous diagnosis of depression or anxiety. There were no significant differences in depression scores by age. Almost half the participants reported some level of psychological distress over the past month. Only $11 \%$ of those with mild to severe psychological distress reported previously being diagnosed with depression or anxiety. The prevalence of psychological distress symptoms was comparable across age groups (Table 5). 


\section{Overweight and obesity}

A quarter of participants were overweight and $11 \%$ had obesity, with significant differences by gender (Figure 5). The median BMI for males was significantly lower than for females. A greater proportion of participants aged 18-19 years were overweight or obese compared to the other age groups (Table 5).

\section{Abdominal obesity}

There was a markedly significant difference in the waist-hip ratio (WHR) of males and females, with more than a quarter of females and no males with central obesity (Table 4). Using the WHtR, $44 \%$ of females had central obesity compared to $14 \%$ of males. WC increased with age, with those aged 22-24 years having the highest WC, but WHR did not differ by age. It is important to note that a quarter of participants with normal BMI had abnormal WHR and/or WHtR and could be classified as having central obesity.

\section{Discussion}

This study describes the prevalence of NCDs and NCD risk factors among South African AYLHIV in an urban setting. Previous studies in SSA have described NCD comorbidities in adults living with HIV [23]. Few studies have assessed the prevalence of NCDs and particularly NCD risk factors in AYLHIV in SSA. Risk behaviour research on AYLHIV in SSA has predominantly focused on sexual risk behaviour [70]. We therefore set out to investigate NCD multimorbidity and risk factors in this population group given the emerging NCD epidemic in SSA occurring against a background of a high HIV burden and increased comorbidity risk in PLHIV.

We highlight several key findings. Almost half of our participants experienced significant symptoms of depression and psychological distress. More than a third were overweight or obese, a third had insufficient levels of weekly physical activity and the majority did not meet dietary guidelines for fruit and vegetable intake. There was low nutritional knowledge, particularly on healthy food choices and dietdisease relationships. A detailed interpretation of these findings, comparisons to the general population and previous findings in PLHIV as well as implications for integrated prevention are discussed below.

More than two-thirds of our respondents were female which reflects the gendered nature of the HIV epidemic in South Africa [71], and much higher rates of health care-seeking among young women compared to young men [72]. A greater proportion of AYLHIV in this study were multidimensionally poor compared to national estimates which indicate that $33.4 \%$ of young people aged $15-24$ years are MPI poor [73]. Although the proportion of NEETs in this study was lower than the national average of 34\% [74], they experienced other dimensions of deprivation which may interact to exacerbate vulnerability to NCDs.

Previous studies in South Africa corroborate the findings that HIV/AIDS-affected and infected youth face multiple deprivations of poverty [75,76], and food insecurity [77], which are commonly cited challenges for adolescents receiving HIV treatment and care in SSA. This is concerning because socioeconomic 
factors impact adherence to ART and retention in HIV care, which has implications for viral suppression and chronic disease pathways [78,79]. Addressing this challenge requires a multi-sectoral approach for NCD prevention with appropriate social protection systems to meet the needs of AYLHIV.

With respect to NCD risk factors associated with behaviour and knowledge, we found that almost threequarters of AYLHIV did not meet recommended dietary guidelines of eating at least five portions of fruit and vegetables daily necessary to reduce the risk of NCDs [80]. Compared to provincial estimates for youth in the Western Cape, more respondents, particularly females, consumed deep-fried foods and fastfoods daily, while the proportion who consumed SSB daily was lower than the provincial average (42\%) [10] and estimates from 44 other LMICs (44\%) [81]. A meta-analysis on SSB intake found that individuals who consumed 1-2 servings per day had a $26 \%$ greater risk of developing type 2 diabetes mellitus (T2DM), and a $20 \%$ greater risk of metabolic syndrome compared to those who did not consume SSB or had less than one serving/month [82]. Although the South African government has made strides in promoting healthier food environments by implementing mandatory legislation for salt reduction in processed foods [83] and a tax on SSB [84], our findings suggest that greater efforts are needed to translate these measures into action at a community and household level, especially amongst young girls who have higher prevalence of obesity which is likely to persist until adulthood without intervention.

Our results support findings of gender differences in physical activity levels among South African adolescents similar to global reports $[85,86]$. More than two-thirds of our respondents used active transport; either walking to and from school or work. This is notable and important that future interventions to increase physical activity consider strategies to retain this healthy behaviour. However, fewer than one-third had sufficient levels of physical activity necessary to promote health and prevent chronic diseases. This is similar to physical inactivity levels reported in urban-based South African students [85]. The proportion who spent more than three hours per day sedentary was higher than general population estimates of $30 \%$ [14] and higher than estimates from other LMICs of $27 \%$ [81].

Our results are consistent with those from a study conducted in Botswana which found that youth living with HIV had significantly lower levels of daily physical activity compared to HIV negative controls [87]. Similarly, a study in Brazil in 10-15-year-old perinatally-infected adolescents found that participants living with HIV had lower physical activity scores compared to healthy peers [88]. Additional research is needed in this setting to explore the relationship between physical activity and HIV in adolescents. A study with an age-and sex-matched HIV-negative control group from the same community would help to elucidate whether this relationship exists in South Africa.

Participants scored low on general nutrition knowledge questions and particularly had poor knowledge of healthy food choices and associations between diet and diseases. To our knowledge, this is the first study to assess nutrition knowledge in AYLHIV in Africa. A South African study in school-going adolescents aged 15-18 years found that $77.5 \%$ scored below average on diet and nutrition knowledge questions [89]. The poor knowledge on nutrition-related NCDs amongst AYLHIV in our study is concerning in a country undergoing nutritional transition [90]. Nutrition knowledge is strongly correlated with dietary 
intake and is needed for better dietary habits [57]. Although adolescents may lack autonomy in navigating their food environment, this life stage is characterised by increasing independence highlighting the importance of good dietary knowledge including how diet affects their current and future health [89] to support making healthier food choices.

Our blood pressure findings are consistent with findings from studies in adolescents in the general population of urban South Africa which have reported hypertension prevalence rates ranging from 8-16\% [91] and elevated BP prevalence of 35\% [92]. A study in the United States reported a significantly higher prevalence of elevated blood pressure in a cohort of HIV-infected, predominantly African-American adolescents and young adults compared to healthy children [93]. Globally, studies involving HIV-infected adults have demonstrated higher hypertension prevalence than the general population [94] and hypertension has been found to be associated with ART [95,96]. One in five young adults (18-35 years) attending an HIV clinic in the same setting in Khayelitsha were found to have comorbid hypertension [97]. There are conflicting data on the link between HIV infection and elevated BP in paediatric populations. Nevertheless, our findings support the need for routine monitoring of BP in HIV care, even in younger populations, in settings like South African with a high background prevalence of hypertension, in order to avert future disease.

None of those with self-reported diabetes symptoms had an abnormal random blood glucose. In a cohort study of South African youth living with perinatally-acquired HIV, the authors found a high prevalence of insulin resistance but this did not differ from that in HIV-negative age-matched adolescents [98]. A systematic review and meta-analysis of African studies recently reported that there was no statistically significant association between HIV infection or ART exposure and T2DM in adults [99]. This is in contrast to findings from European and North American studies that have shown a higher prevalence of T2DM in HIV-positive adults particularly those on ART [100-102]. The International Diabetes Federation (IDF) estimates that $60 \%$ of people with diabetes in Africa are undiagnosed [103] suggesting that T2DM might be a major, underdiagnosed public health problem in African populations in general, warranting further attention.

We found high levels of depression and psychological distress in our study compared to less than a quarter of young people nationally [12]. Concerningly, only $11 \%$ of those with mild to severe psychological distress reported previously being diagnosed with a mental health condition highlighting a significant gap in care. Mental health conditions are prevalent in AYLHIV in both high-income and resource-limited settings [104]. Our results are generally consistent with prevalence rates of depression among children and adolescents living with HIV from other African countries ranging from $18.9 \%$ in Malawi [105] to $51.2 \%$ prevalence of psychological distress in Uganda [106].

Notably, significantly more female participants reported depressive symptoms compared to males which is in line with global statistics on depression [107]. Our findings show that only $17 \%$ of those identified as having significant depression reported being previously diagnosed with anxiety or depression. In a previous retrospective review in the same population, mental health conditions were documented in less 
than $5 \%$ of clinic records reviewed [35]. In a recent study conducted in South Africa, the authors found similar rates of mental illness in perinatally-infected and uninfected adolescents, suggesting that other prevalent social factors in the community may override the effect of HIV, especially in the ART era [108]. Nevertheless, these findings highlight that there is a significant missed opportunity for identifying youth with mental health problems in our setting.

More than a third of our respondents were overweight or had obesity, with significantly more overweight and centrally obese females compared to males. Although our rates of overweight and obesity are slightly lower than prevalence rates for youth in the Western Cape (31.5\% overweight and $11.3 \%$ obese) [14], our rates appear similar to obesity trends in the general population. A previous study in adult patients attending primary health care HIV-clinics in South Africa found that more than half of female patients were overweight or had obesity compared to $16 \%$ of male patients [109]. Obesity in PLHIV is well documented in high-income countries and is emerging as a major challenge in Africa [24] with several studies showing increased rates of obesity in PLHIV $[109,110]$. But few studies in Africa have reported on overweight and obesity levels in AYLHIV other than in the context of ART-associated dyslipidaemia $[87,111,112]$. One study conducted among South African university students living with HIV (the majority aged $20-25$ years) found that $21 \%$ were overweight and $30 \%$ had obesity [113]. Our results are consistent with these findings and confirm results from a folder review conducted in this same population that reported similar levels of overweight and obesity [35].

In addition to BMI, we assessed central obesity using waist and hip circumference indicators and found that $26 \%$ of our respondents with normal BMI had high WHR or WHtR, meeting criteria for central obesity. Another South African study in adults attending three HIV-clinics reported a high prevalence of central obesity, primarily in women $-45 \%$ (4\% in men) [113].

\section{Implications for integrated care}

Our findings underscore the importance of anthropometry beyond BMI, especially in females. In a comparison of anthropometric measures in HIV patients in Cameroon, Dimala et al found that markers of adiposity like WC, WHR and WHtR are better than BMI at identifying HIV/AIDS patients with increased cardiometabolic risk [114]. In our study, obesity co-occurred with hypertension - 35\% of those with elevated BP or hypertension were also overweight or obese (data not shown). By screening for obesity, other related conditions which tend to cluster with obesity can also be detected. Given that anthropometric measurements and calculations are non-invasive, low-cost and easy-to-use interventions, our findings support the need to integrate this screening into routine care to identify AYLHIV who are at increased cardiometabolic risk and intervene early as they transition into adulthood, especially with prolonged exposure to ART regimens which are linked to obesity, altered glucose metabolism and dyslipidaemia [115]. This is supported by the WHO and the IDF who recommend monitoring changes in WC in addition to measuring BMI, particularly in HIV-positive populations on ART and in female patients who have a higher prevalence of obesity $[68,116]$. 
Recommendations calling for integration of mental health services into HIV care have been made for adults [117] given the multiple psychological vulnerabilities associated with living with HIV and high rates of suicide in PLHIV $[118,119]$. Our findings further support the need for integration of mental health screening in HIV care for AYLHIV. A study conducted in Johannesburg found that a simple way of identifying youth struggling with mental health problems at primary care level is by asking them about their future aspirations. Those who do not feel like they have control of their future or do not have a dream for the future were found to be more likely to have symptoms of depression, anxiety or PTSD requiring further support [120].

The recently introduced integrated chronic disease management (ICDM) model in South Africa recognises the importance of monitoring both chronic communicable and NCDs in order to achieve optimal clinical outcomes [121]. Our findings underscore the importance of applying an evidence-based integrated approach to the healthcare services for AYLHIV. In the context of resource limitations, further research exploring the multilevel determinants of these NCDs and their risk factors would be useful to inform tailored strategies to identify those at highest risk.

\section{Strengths and Limitations}

Our study adds to the limited evidence base on NCD prevalence and risk factors in AYLHIV in SSA. To our knowledge, only four other studies in SSA have investigated modifiable NCD risk factors besides alcohol and substance use in AYLHIV $[87,113,122,123]$. While our study provides novel findings for the subSaharan African context, we note some limitations.

The low response rate and lack of random sampling may limit the generalizability of our findings, however sampling from six different facilities across all substructures in the City of Cape Town mitigated unmeasured facility-specific effects. Although we recruited younger adolescents, requiring parental consent may have led to participant bias as the majority enrolled were older adolescents and young adults who could provide independent consent to participate.

We utilised subjective recall methods to asses physical activity which may be prone to over-reporting, recall bias and cultural misinterpretation. However, self-report methods like the IPAQ have acceptable validity and have been widely used to measure physical activity in PLHIV in similar contexts allowing for some comparability [25]. The use of POC random blood glucose testing may have underestimated diabetes risk, however, POC methods are better suited for community screening of diabetes, have high specificity and provide reliable and immediate results [124]. Similarly, the mental health tools used are screening and not diagnostic tools. But they are appropriate for case-finding in primary care and have been validated in HIV-positive populations in South Africa [64,65]. Despite these limitations, this study represents an important contribution to the limited literature on HIV / NCD multimorbidity in adolescents and youth in SSA.

\section{Conclusions}


This paper contributes to a key gap in the literature on NCD risk in AYLHIV in SSA. The findings highlight the existence of cardiometabolic risk factors (obesity, abdominal obesity, hypertension, physical inactivity, unhealthy diet) and mental ill-health in this vulnerable population, highlighting the need for integrated comprehensive care for AYLHIV with NCD screening and integrated primary and secondary prevention.

NCDs and their ensuing burden of disability and premature mortality are costly to health systems and to wider societal development. Beyond primary care, the complex and interlinked social, economic and environmental factors that influence these behaviours highlight the importance of intersectoral action for disease prevention. Addressing these root causes will therefore necessitate intervention beyond the healthcare sector to address the social, economic and environmental exposures that increase the risk of NCDs and ill-health, and to support equitable access to the necessary physical and social infrastructure required to make the healthy choice the easy choice. More studies are needed to assess risk factors at a broader socio-ecological level and explore inter-relationships between HIV / NCD comorbidity and the multilevel determinants of multimorbidity.

\section{List Of Abbreviations}

AYLHIV:

BMl:

BP:

CESD-10:

CMNN:

FFQ:

GNKQ:

HFIAS:

IDF:

IPAQ:

K10:

LMIC:

MET:

NCD:
Adolescents and youth living with HIV;

Body mass index;

Blood pressure;

Centre for Epidemiological Studies Short Depression Scale; Communicable, Maternal, Neonatal, and Nutritional;

Food frequency questionnaire;

General Nutrition Knowledge Questionnaire;

Household Food Insecurity Access Scale;

International Diabetes Federation;

International Physical Activity Questionnaire;

Kessler Psychological Distress Scale;

Low- and middle-income countries;

Metabolic equivalent of task;

Non-communicable disease; 
NEET: $\quad$ Neither in education, employment or training;

PA: $\quad$ Physical activity;

PLHIV: $\quad$ People living with HIV;

PTSD: $\quad$ Post-traumatic stress disorder

SSA: $\quad$ Sub-Saharan Africa;

SSB: $\quad$ Sugar-sweetened beverages;

T2DM: $\quad$ Type 2 diabetes mellitus

WHO: $\quad$ World Health Organization;

WC: $\quad$ Waist circumference;

WHR: Waist-hip ratio;

WHtR: Waist-to-height ratio;

YMPI: $\quad$ Youth Multidimensional Poverty Index.

\section{Declarations}

Ethics approval and consent to participate: This study was performed in line with the principles of the Declaration of Helsinki. Approval was granted by the Human Research Ethics Committee in the Faculty of Health Sciences at the University of Cape Town (HREC ref.no 520/2017), and the Health Research Ethics Committees of the City of Cape Town and the Western Cape provincial government. Written informed consent was obtained from all individual participants included in the study. Parental or caregiver written consent and participant assent were obtained for participants younger than 18 years old.

Consent for publication: Not applicable.

Availability of data and materials: The data that support the findings of this study are not publicly available due to the sensitive nature of information that could compromise minor research participants' privacy/consent but are available from the corresponding author MK on reasonable request.

Competing interests: The authors declare that they have no competing interests.

Funding: This work was supported by a Bristol-Myers Squibb Foundation grant awarded to TO (grant number 430960). MK was supported by the South African National Research Foundation (NRF) under joint funding with the German Academic Exchange Service (DAAD) for her PhD. TO is also supported by the National Institute for Health Research (NIHR) (Global Health Research Units and Groups Programme) 
for a Global Health Research Group and Network on Diet and Activity. The views expressed in this publication are those of the authors and not necessarily those of the National Health Service (NHS), the NIHR or the Department of Health and Social Care. Funding from NIHR $(16 / 137 / 34)$ is gratefully acknowledged. The funding bodies had no role in the design of the study, data collection, analysis, interpretation of data or in writing the manuscript.

Authors' contributions: MK and TO conceptualized the study. MK and BG conducted data collection. MK conducted data analysis and interpretation and wrote the first draft of the manuscript. TO contributed to data interpretation and manuscript preparation. All authors read and approved the final manuscript.

Acknowledgments: We appreciate the assistance from the City of Cape Town and Western Cape Departments of Health who made access to the facilities and participants possible. We would like to acknowledge and thank the adolescents and youth who agreed to make themselves available to take part in this research and share their insights and experiences with us.

Authors' information: See Title page.

\section{References}

1. Naghavi M. Global, regional, and national burden of suicide mortality 1990 to 2016 : systematic analysis for the Global Burden of Disease Study 2016. BMJ. 2019:194.

2. Vos T, Abajobir AA, Abate $\mathrm{KH}$, et al. Global, regional, and national incidence, prevalence, and years lived with disability for 328 diseases and injuries for 195 countries, 1990-2016: a systematic analysis for the Global Burden of Disease Study 2016. The Lancet. 2017;390(10100):1211-1259.

3. World Health Organization. Noncommunicable diseases. 2018; Media centre, Fact sheet Available at: https://www.who.int/news-room/fact-sheets/detail/noncommunicable-diseases. Accessed 21 April 2020, 2020.

4. Lee IM, Shiroma EJ, Lobelo F, Puska P, Blair SN, Katzmarzyk PT. Effect of physical inactivity on major non-communicable diseases worldwide: an analysis of burden of disease and life expectancy. The Lancet. 2012;380(9838):219-229.

5. Forouzanfar MH, Afshin A, Alexander LT, et al. Global, regional, and national comparative risk assessment of 79 behavioural, environmental and occupational, and metabolic risks or clusters of risks, 1990-2015: a systematic analysis for the Global Burden of Disease Study 2015. The Lancet. 2016;388(10053):1659-1724.

6. Gouda HN, Charlson F, Sorsdahl K, et al. Burden of non-communicable diseases in sub-Saharan Africa, 1990-2017: results from the Global Burden of Disease Study 2017. The Lancet Global Health. 2019;7(10):e1375-e1387.

7. Remais JV, Zeng G, Li G, Tian L, Engelgau MM. Convergence of non-communicable and infectious diseases in low-and middle-income countries. International journal of epidemiology. 2013;42(1):221227. 
8. Kengne AP. Trends in obesity and diabetes across Africa from 1980 to 2014: an analysis of pooled population-based studies. Int J Epidemiol. Oct 1 2017;46(5):1421-1432.

9. Mayosi BM, Flisher AJ, Lalloo UG, Sitas F, Tollman SM, Bradshaw D. The burden of noncommunicable diseases in South Africa. The Lancet. 2009;374(9693):934-947.

10. National Department of Health (NDoH), Statistics South Africa (Stats SA), South African Medical Research Council (SAMRC), and ICF. South Africa demographic and health survey 2016. NDoH, Stats SA, SAMRC, \& ICF. 2019.

11. World Health Organization. Noncommunicable diseases progress monitor 2020. Geneva: World Health Organization; 10 February 2020 2020. 978-92-4-000049-0.

12. Shisana O. The South African National Health and Nutrition Examination Survey: SANHANES-1: HSRC press; 2013.

13. World Health Organization. Global status report on alcohol and health 2018: World Health Organization; 2019.

14. Reddy S, James S, Sewpaul R, et al. Umthente uhlaba usamila: the 3rd South African national youth risk behaviour survey 2011. 2013.

15. Sawyer SM, Afifi RA, Bearinger LH, et al. Adolescence: a foundation for future health. Lancet. Apr 28 2012;379(9826):1630-1640.

16. Azzopardi P. Adolescent health comes of age. The Lancet. 2012;379(9826):1583-1584.

17. Ng M, Fleming T, Robinson M, Thomson B, Graetz N, Margono C et al. Global, regional, and national prevalence of overweight and obesity in children and adults during 1980-2013: a systematic analysis for the Global Burden of Disease Study 2013. Lancet (London, England). 05/29 2014;384(9945):766-781.

18. Rossouw HA, Grant CC, Viljoen M. Overweight and obesity in children and adolescents: The South African problem. South African Journal of Science. 2012;108(5-6):31-37.

19. Dagadu HE, Patterson EJ. Placing a Health Equity Lens on Non-communicable Diseases in subSaharan Africa. J Health Care Poor Underserved. Aug 2015;26(3):967-989.

20. Pillay-Van Wyk V, Msemburi W, Laubscher R, et al. Mortality trends and differentials in South Africa from 1997 to 2012: second National Burden of Disease Study. The Lancet Global Health. 2016;4(9):e642-e653.

21. UNAIDS. Country factsheets: South Africa 2019. 2019;Available at: https://www.unaids.org/en/regionscountries/countries/southafrica. Accessed 17 January 2021, 2021.

22. UNAIDS. Key HIV epidemiology indicators for children and adolescents aged 0-19, 2000-2018. 2019; Available at: http://aidsinfo.unaids.org/. Accessed 28 April 2020, 2020.

23. Patel P, Rose CE, Collins PY, et al. Noncommunicable diseases among HIV-infected persons in lowincome and middle-income countries: a systematic review and meta-analysis. AIDS (London, England). 2018;32(Suppl 1):S5. 
24. Deeks SG, Lewin SR, Havlir DV. The End of AIDS: HIV Infection as a Chronic Disease. Lancet. 10/23 2013;382(9903):1525-1533.

25. Vancampfort D, Mugisha J, De Hert M, et al. Global physical activity levels among people living with HIV: a systematic review and meta-analysis. Disability and Rehabilitation. 2018;40(4):388-397.

26. Reynolds NR. Cigarette smoking and HIV: more evidence for action. AIDS Educ Prev. Jun 2009;21(3 Suppl):106-121.

27. Petrosillo N, Cicalini S. Smoking and HIV: time for a change? BMC medicine. 2013;11(1):16.

28. Scott-Sheldon LAJ, Walstrom P, Carey KB, Johnson BT, Carey MP. Alcohol Use and Sexual Risk Behaviors among Individuals Infected with HIV: A Systematic Review and Meta-Analysis 2012 to Early 2013. Current HIV/AIDS Reports. 2013;10(4):314-323.

29. Kalichman S, Mathews C, Banas E, Kalichman M. Alcohol-related intentional nonadherence to antiretroviral therapy among people living with HIV, Cape Town, South Africa. AIDS Care. 2019;31(8):951-957.

30. Kader R, Govender R, Seedat S, Koch JR, Parry C. Understanding the Impact of Hazardous and Harmful Use of Alcohol and/or Other Drugs on ARV Adherence and Disease Progression. PLoS One. 2015;10(5):e0125088.

31. Battles HB, Wiener LS. From adolescence through young adulthood: psychosocial adjustment associated with long-term survival of HIV. Journal of adolescent health. 2002;30(3):161-168.

32. Achwoka D, Waruru A, Chen TH, et al. Noncommunicable disease burden among HIV patients in care: a national retrospective longitudinal analysis of HIV-treatment outcomes in Kenya, 2003-2013. BMC public health. Apr 3 2019;19(1):372.

33. Beksinska ME, Pillay L, Milford C, Smit JA. The sexual and reproductive health needs of youth in South Africa-history in context. South African Medical Journal. 2014;104(10):676-678.

34. Nagata JM, Hathi S, Ferguson BJ, Hindin MJ, Yoshida S, Ross DA. Research priorities for adolescent health in low- and middle-income countries: A mixed-methods synthesis of two separate exercises. $J$ Glob Health. Jun 2018;8(1):010501.

35. Kamkuemah M, Gausi B, Oni T. Missed opportunities for NCD multimorbidity prevention in adolescents and youth living with HIV in urban South Africa. BMC public health. 2020;20(821).

36. Okawa S, Mwanza-Kabaghe S, Mwiya M, et al. Sexual and reproductive health behavior and unmet needs among a sample of adolescents living with HIV in Zambia: a cross-sectional study. Reprod Health. Mar 27 2018;15(1):55.

37. Toska E, Pantelic M, Meinck F, Keck K, Haghighat R, Cluver L. Sex in the shadow of HIV: A systematic review of prevalence, risk factors, and interventions to reduce sexual risk-taking among HIV-positive adolescents and youth in sub-Saharan Africa. PLOS ONE. 2017;12(6):e0178106.

38. Jewkes R, Dunkle K, Nduna M, et al. Factors associated with HIV sero-status in young rural South African women: connections between intimate partner violence and HIV. International Journal of Epidemiology. 2006;35(6):1461-1468. 
39. Mbalinda SN, Kiwanuka N, Kaye DK, Eriksson LE. Reproductive health and lifestyle factors associated with health-related quality of life among perinatally HIV-infected adolescents in Uganda. Health and Quality of Life Outcomes. 2015;13(1).

40. Western Cape Government. 2017 Socio-economic Profile: City of Cape Town. In: Department of Social Development, ed. Cape Town2017.

41. Cape Metro Health Department. CAPE METRO DISTRICT HEALTH PLAN 2018/19 - 2020/21. In: DM T, ed. Cape Town2018.

42. Statistics South Africa. P0309.3 Mortality and causes of death in South Africa, 2015: Findings from death notification. Available at: http://www.statssa.gov.za/publications/P03093/P030932015.pdf. Accessed 15 June 2020.

43. Klein H. Adolescence, youth, and young adulthood: Rethinking current conceptualizations of life stage. Youth \& society. 1990;21(4):446-471.

44. Statistics South Africa. Census Questionnaire. 2011; Available at: http://www.statssa.gov.za/? page_id=3852. Accessed 29 April, 2020.

45. Alkire S, Santos ME. Acute multidimensional poverty: A new index for developing countries. 2010.

46. Ballard T, Coates J, Swindale A, Deitchler M. Household hunger scale: indicator definition and measurement guide. Food and Nutrition Technical Assistance I/ Project, FHI. 2011;360.

47. Coates J, Swindale A, Bilinsky P. Household Food Insecurity Access Scale (HFIAS) for measurement of food access: indicator guide: version 3. 2007.

48. Craig C, Marshall A, Sjostrom M, et al. International Physical Activity Questionnaire-Short Form. 2017.

49. Craig CL, Marshall AL, Sjöström M, et al. International physical activity questionnaire: 12-country reliability and validity. Medicine \& science in sports \& exercise. 2003;35(8):1381-1395.

50. Ainsworth BE, Haskell WL, Whitt MC, et al. Compendium of physical activities: an update of activity codes and MET intensities. Medicine \& science in sports \& exercise. 2000;32(9):S498-S516.

51. IPAQ Research Committee. Guidelines for data processing and analysis of the International Physical Activity Questionnaire (IPAQ)-short and long forms. Available at: http://www. ipaq. ki. se/scoring. pdf. 2005. Accessed August 2020.

52. World Health Organization. WHO Global recommendations on physical activity for health. Geneva: World Health Organization; 2011. Geneva, Switzerland: World Health Organization; 2011.

53. Guthold R, Cowan MJ, Autenrieth CS, Kann L, Riley LM. Physical activity and sedentary behavior among schoolchildren: a 34-country comparison. The Journal of pediatrics. 2010;157(1):43-49. e41.

54. Katzmarzyk PT, Barreira TV, Broyles ST, et al. The international study of childhood obesity, lifestyle and the environment (ISCOLE): design and methods. BMC public health. 2013;13(1):900.

55. Saloheimo T, González SA, Erkkola M, et al. The reliability and validity of a short food frequency questionnaire among 9-11-year olds: a multinational study on three middle-income and high-income countries. International Journal of Obesity Supplements. 2015;5(S2):S22-S28. 
56. Kliemann N, Wardle J, Johnson F, Croker H. Reliability and validity of a revised version of the General Nutrition Knowledge Questionnaire. European journal of clinical nutrition. 2016;70(10):1174-1180.

57. Wardle J, Parmenter K, Waller J. Nutrition knowledge and food intake. Appetite. 2000;34(3):269-275.

58. Karl Peltzer K-N. Nutrition knowledge among a sample of urban black and white South Africans. South African Journal of Clinical Nutrition. 2004;17(1):24-31.

59. Miller MR, Hankinson J, Brusasco V, et al. Standardisation of spirometry. European respiratory journal. 2005;26(2):319-338.

60. Seedat Y, Rayner B, Veriava Y. South African hypertension practice guideline 2014. Cardiovascular journal of Africa. 2014;25(6):288.

61. Andresen EM, Malmgren JA, Carter WB, Patrick DL. Screening for depression in well older adults: Evaluation of a short form of the CES-D. American journal of preventive medicine. 1994;10(2):77-84.

62. Radloff LS. The CES-D scale: A self-report depression scale for research in the general population. Applied psychological measurement. 1977;1(3):385-401.

63. Kessler RC, Barker PR, Colpe LJ, et al. Screening for serious mental illness in the general population. Archives of general psychiatry. 2003;60(2):184-189.

64. Myer L, Smit J, Roux LL, Parker S, Stein DJ, Seedat S. Common mental disorders among HIV-infected individuals in South Africa: prevalence, predictors, and validation of brief psychiatric rating scales. AIDS patient care and STDs. 2008;22(2):147-158.

65. Spies G, Kader K, Kidd M, et al. Validity of the K-10 in detecting DSM-IV-defined depression and anxiety disorders among HIV-infected individuals. AIDS care. 2009;21(9):1163-1168.

66. Radloff LS. The use of the Center for Epidemiologic Studies Depression Scale in adolescents and young adults. Journal of youth and adolescence. 1991;20(2):149-166.

67. Andrews G, Slade T. Interpreting scores on the Kessler psychological distress scale (K10). Australian and New Zealand journal of public health. 2001;25(6):494-497.

68. World Health Organization. Waist circumference and waist-hip ratio: report of a WHO expert consultation, Geneva, 8-11 December 2008. 2011.

69. Browning LM, Hsieh SD, Ashwell M. A systematic review of waist-to-height ratio as a screening tool for the prediction of cardiovascular disease and diabetes: 0.5 could be a suitable global boundary value. Nutrition Research Reviews. 2010;23(2):247-269.

70. Ssewanyana D, Mwangala PN, Van Baar A, Newton CR, Abubakar A. Health risk behaviour among adolescents living with HIV in sub-Saharan Africa: a systematic review and meta-analysis. BioMed research international. 2018;2018.

71. Shisana O, Rehle T, Simbayi LC, et al. South African national HIV prevalence, incidence and behaviour survey, 2012. 2014.

72. Dellar RC, Dlamini S, Karim QA. Adolescent girls and young women: key populations for HIV epidemic control. Journal of the International AIDS Society. 2015;18(2(Suppl 1)):19408. 
73. Statistics South Africa. Living Conditions of Households in South Africa. An analysis of household expenditure and income data using the Living Conditions Survey LCS 2014/2015..

74. Statistics South Africa. Quarterly Labour Force Survey, Quarter 1: 2019. Pretoria: Statistics South Africa. Retrieved August. 2019; 22:2019..

75. Sherr L, Cluver LD, Toska E, He E. Differing psychological vulnerabilities among behaviourally and perinatally HIV infected adolescents in South Africa - implications for targeted health service provision. AIDS Care. Jun 2018;30(sup2):92-101.

76. Cluver L, Gardner F, Operario D. Poverty and psychological health among AIDS-orphaned children in Cape Town, South Africa. AIDS care. 2009;21(6):732-741.

77. Young S, Wheeler AC, McCoy SI, Weiser SD. A review of the role of food insecurity in adherence to care and treatment among adult and pediatric populations living with HIV and AIDS. AIDS and Behavior. 2014;18(5):505-515.

78. Agu CE, Uchendu IK, Nsonwu AC, Okwuosa CN, Achukwu PU. Prevalence and associated risk factors of peripheral artery disease in virologically suppressed HIV-infected individuals on antiretroviral therapy in Kwara state, Nigeria: a cross sectional study. BMC public health. Aug 20 2019;19(1):1143.

79. Innes S, Patel K. Noncommunicable diseases in adolescents with perinatally acquired HIV-1 infection in high-income and low-income settings. Curr Opin HIV AIDS. May 2018;13(3):187-195.

80. World Health Organization. Healthy diet. World Health Organization. Regional Office for the Eastern Mediterranean;2019.

81. Ashdown-Franks G, Vancampfort D, Firth J, et al. Association of leisure-time sedentary behavior with fast food and carbonated soft drink consumption among 133,555 adolescents aged 12-15years in 44 low- and middle-income countries. International Journal of Behavioral Nutrition and Physical Activity. 2019;16(1).

82. Malik VS, Popkin BM, Bray GA, Despres JP, Willett WC, Hu FB. Sugar-Sweetened Beverages and Risk of Metabolic Syndrome and Type 2 Diabetes: A meta-analysis. Diabetes Care. 2010;33(11):24772483.

83. National Assembly Republic of South Africa. South Africa. Foodstuffs, Cosmetics and Disinfectants Act of 1972. Regulations: Reduction of sodium in certain foodstuffs and related matters. In: Africa GoS, ed. R. 533/2012: Government Gazette; 2012.

84. Arthur R. South Africa introduces sugar tax. Beverage Daily,2018 Available at: www. beveragedaily. com/Article/2018/04/03/South-Africa-introduces-sugar-tax Accessed 30 January 2019.

85. Van Biljon A, McKune AJ, Dubose KD, Kolanisi U, Semple SJ. Physical activity levels in urban-based South African learners: A cross-sectional study of 7348 participants. South African Medical Journal. 2018;108(2):126.

86. McVeigh J, Meiring R. Physical activity and sedentary behavior in an ethnically diverse group of South African school children. Journal of sports science \& medicine. 2014;13(2):371.

87. Malete L, Tladi DM, Etnier JL, Makhanda J, Anabwani GM. Examining psychosocial correlates of physical activity and sedentary behavior in youth with and without HIV. PLOS One. 
2019;14(12):e0225890.

88. Martins PC, Lima LRA, Teixeira DM, Carvalho AP, Petroski EL. PHYSICAL ACTIVITY AND BODY FAT IN ADOLESCENTS LIVING WITH HIV: A COMPARATIVE STUDY. Rev Paul Pediatr. Jan-Mar 2017;35(1):69-77.

89. Letlape SV, Mokwena K, Oguntibeju O. Knowledge of students attending a high school in pretoria, South Africa, on diet, nutrition and exercise. West Indian Medical Journal. 2010;59(6):633-640.

90. Bourne LT, Lambert EV, Steyn K. Where does the black population of South Africa stand on the nutrition transition? Public health nutrition. Feb 2002;5(1a):157-162.

91. Kagura J, Adair LS, Musa MG, Pettifor JM, Norris SA. Blood pressure tracking in urban black South African children: birth to twenty cohort. BMC pediatrics. 2015;15(1):78.

92. Naidoo S, Kagura J, Fabian J, Norris SA. Early Life Factors and Longitudinal Blood Pressure Trajectories Are Associated With Elevated Blood Pressure in Early Adulthood. Hypertension. 2019;73(2):301-309.

93. Chatterton-Kirchmeier S, Camacho-Gonzalez AF, McCracken CE, Chakraborty R, Batisky DL. Increased prevalence of elevated blood pressures in HIV-infected children, adolescents and young adults. The Pediatric infectious disease journal. Jun 2015;34(6):610-614.

94. Fahme SA, Bloomfield GS, Peck R. Hypertension in HIV-Infected Adults. Hypertension. 2018;72(1):4455.

95. Nduka C, Stranges S, Sarki A, Kimani P, Uthman O. Evidence of increased blood pressure and hypertension risk among people living with HIV on antiretroviral therapy: a systematic review with meta-analysis. Journal of Human Hypertension. 2016;30(6):355-362.

96. Pangmekeh PJ, Awolu MM, Gustave S, Gladys T, Cumber SN. Association between highly active antiretroviral therapy (HAART) and hypertension in persons living with HIV/AIDS at the Bamenda regional hospital, Cameroon. Pan Afr Med J. 2019;33:87.

97. Oni T, Youngblood E, Boulle A, McGrath N, Wilkinson RJ, Levitt NS. Patterns of HIV, TB, and noncommunicable disease multi-morbidity in peri-urban South Africa- a cross sectional study. BMC infectious diseases. 2015;15:20.

98. Frigati LJ, Jao J, Mahtab S, et al. Insulin Resistance in South African Youth Living with Perinatally Acquired HIV Receiving Antiretroviral Therapy. AIDS Research and Human Retroviruses. 2019;35(1):56-62.

99. Prioreschi A, Munthali RJ, Soepnel L, et al. Incidence and prevalence of type 2 diabetes mellitus with HIV infection in Africa: a systematic review and meta-analysis. BMJ open. Mar 29 2017;7(3):e013953.

100. Brown TT, Cole SR, Li X, et al. Antiretroviral therapy and the prevalence and incidence of diabetes mellitus in the multicenter AIDS cohort study. Archives of internal medicine. 2005;165(10):11791184.

101. De Wit S, Sabin CA, Weber R, et al. Incidence and risk factors for new-onset diabetes in HIV-infected patients the data collection on adverse events of anti-HIV drugs (D: A: D) study. Diabetes care. 
2008;31(6):1224-1229.

102. Tripathi A, Liese AD, Jerrell JM, et al. Incidence of diabetes mellitus in a population-based cohort of HIV-infected and non-HIV-infected persons: the impact of clinical and therapeutic factors over time. Diabet Med. Oct 2014;31(10):1185-1193.

103. Saeedi P, Petersohn I, Salpea P, Malanda B, Karuranga S, Unwin N, et al. Global and regional diabetes prevalence estimates for 2019 and projections for 2030 and 2045: Results from the International Diabetes Federation Diabetes Atlas. Diabetes research and clinical practice. 2019 Nov 1;157:107843.

104. Vreeman RC, McCoy BM, Lee S. Mental health challenges among adolescents living with HIV. J Int AIDS Soc. May 16 2017;20(Suppl 3):21497.

105. Kim MH, Mazenga AC, Yu X, et al. Factors associated with depression among adolescents living with HIV in Malawi. BMC Psychiatry. Oct 26 2015;15:264.

106. Musisi S, Kinyanda E. Emotional and behavioural disorders in HIV seropositive adolescents in urban Uganda. East African medical journal. 2009;86(1).

107. Nolen-Hoeksema S, Girgus JS. The emergence of gender differences in depression during adolescence. Psychological bulletin. 1994;115(3):424.

108. Buckley J, Otwombe K, Joyce C, et al. Mental Health of Adolescents in the Era of Antiretroviral Therapy: Is There a Difference Between HIV-Infected and Uninfected Youth in South Africa? The Journal of adolescent health : official publication of the Society for Adolescent Medicine. Apr 52020.

109. Huis In 'T Veld D, Pengpid S, Colebunders R, Peltzer K. Body Mass Index and Waist Circumference in Patients with HIV in South Africa and Associated Socio-demographic, Health Related and Psychosocial Factors. AIDS and Behavior. 2018;22(6):1972-1986.

110. Castro ADCO, Silveira EA, Falco MDO, Nery MW, Turchi MD. Overweight and abdominal obesity in adults living with HIV/AIDS. Revista da Associação Médica Brasileira. 2016;62(4):353-360.

111. Okechukwu A, Lawson J, Dalilo M. Dyslipidemia in HIV Infected Children and Adolescents on Highly Active Antiretroviral Therapy in Abuja, Nigeria. Journal of Advances in Medicine and Medical Research. 2017:1-11.

112. Innes S, Abdullah KL, Haubrich R, Cotton MF, Browne SH. High prevalence of dyslipidemia and insulin resistance in HIV-infected pre-pubertal African children on antiretroviral therapy. The Pediatric infectious disease journal. 2016;35(1):e1.

113. Steenkamp L, Truter I, Williams M, et al. Nutritional status and metabolic risk in HIV-infected university students: challenges in their monitoring and management. South African Family Practice. 2017;59(1):9-13.

114. Dimala CA, Ngu RC, Kadia BM, Tianyi FL, Choukem SP. Markers of adiposity in HIV/AIDS patients: Agreement between waist circumference, waist-to-hip ratio, waist-to-height ratio and body mass index. PLoS One. 2018;13(3):e0194653.

115. Bakal DR, Coelho LE, Luz PM, et al. Obesity following ART initiation is common and influenced by both traditional and HIV-/ART-specific risk factors. J Antimicrob Chemother. Aug 1 2018;73(8):21772185. 
116. Zimmet $P$, Alberti KGM, Kaufman F, et al. The metabolic syndrome in children and adolescents ? an IDF consensus report. Pediatric Diabetes. 2007;8(5):299-306.

117. Petersen I, Hancock JH, Bhana A, Govender K, Mental Health Care MOPFI. Closing the treatment gap for depression co-morbid with HIV in South Africa: Voices of afflicted women. Health. 2013;05(03):557-566.

118. Kinyanda E, Nakasujja N, Levin J, et al. Major depressive disorder and suicidality in early HIV infection and its association with risk factors and negative outcomes as seen in semi-urban and rural Uganda. J Affect Disord. Apr 1 2017;212:117-127.

119. Casale M, Boyes M, Pantelic M, Toska E, Cluver L. Suicidal thoughts and behaviour among South African adolescents living with HIV: Can social support buffer the impact of stigma? J Affect Disord. Feb 15 2019;245:82-90.

120. Woollett N, Cluver L, Bandeira M, Brahmbhatt $\mathrm{H}$. Identifying risks for mental health problems in HIV positive adolescents accessing HIV treatment in Johannesburg. $J$ Child Adolesc Ment Health. May 2017;29(1):11-26.

121. Asmall S, Mahomed O. Integrated chronic disease management manual. Pretoria: Department of Health. 2013.

122. Jemmott JB, 3rd, Jemmott LS, O'Leary A, et al. Cognitive-behavioural health-promotion intervention increases fruit and vegetable consumption and physical activity among South African adolescents: a cluster-randomised controlled trial. Psychol Health. Feb 2011;26(2):167-185.

123. Ssewanyana D, Newton CR, van Baar A, et al. Beyond Their HIV Status: the Occurrence of Multiple Health Risk Behavior Among Adolescents from a Rural Setting of Sub-Saharan Africa. Int J Behav Med. Mar 252020.

124. Engelgau MM, Narayan KM, Herman WH. Screening for type 2 diabetes. Diabetes Care. 2000;23(10):1563-1580.

\section{Tables}

TABLE 1: Participant Socio-demographic, baseline characteristics by Gender 


\begin{tabular}{|c|c|c|c|c|}
\hline Variable & $\begin{array}{l}\text { Description Median (IQR) or n (\%) } \\
(\mathrm{p}<0.05)^{1}\end{array}$ & $\begin{array}{l}\text { Male: } n= \\
22(24 \%)\end{array}$ & $\begin{array}{l}\text { Female: } \\
\mathrm{n}=70(76 \%)\end{array}$ & $\begin{array}{l}\text { Total } \mathrm{n}= \\
92\end{array}$ \\
\hline \multicolumn{2}{|l|}{ Age (years) } & $\begin{array}{l}20.7(18.9- \\
21.6)\end{array}$ & $\begin{array}{l}20.4(19.0- \\
23.0)\end{array}$ & $\begin{array}{l}20.5 \\
(18.9- \\
22.9)\end{array}$ \\
\hline \multirow{4}{*}{$\begin{array}{l}\text { Adolescent stage by age } \\
\text { group }\end{array}$} & middle adolescence: $15-17$ years & $3(14 \%)$ & $10(15 \%)$ & $13(14 \%)$ \\
\hline & late adolescence: 18-19 years & $5(23 \%)$ & $18(26 \%)$ & $23(26 \%)$ \\
\hline & young adulthood: $20-21$ years & $9(41 \%)$ & $16(24 \%)$ & $25(28 \%)$ \\
\hline & young adulthood: $22-24$ years & $5(23 \%)$ & $24(35 \%)$ & $29(32 \%)$ \\
\hline \multirow{5}{*}{$\begin{array}{l}\text { Family structure- whom they } \\
\text { live with }\end{array}$} & Biological parents & $10(45 \%)$ & $35(50 \%)$ & $45(49 \%)$ \\
\hline & Grandparents & $4(18 \%)$ & $8(11 \%)$ & $12(13 \%)$ \\
\hline & Relative (aunt or uncle) & $6(27 \%)$ & $23(33 \%)$ & $29(32 \%)$ \\
\hline & Siblings & $15(68 \%)$ & $33(47 \%)$ & $48(52 \%)$ \\
\hline & $\begin{array}{l}\text { Non-family (foster care/ children's } \\
\text { home) }\end{array}$ & 0 & $2(3 \%)$ & $2(2 \%)$ \\
\hline \multicolumn{2}{|c|}{ Ever pregnant/ impregnated someone $(p=0.023)$} & $1(5 \%)$ & $19(28 \%)$ & $20(22 \%)$ \\
\hline \multirow[t]{3}{*}{ Parity $(n=20)$} & 0 children & 0 & $5(26 \%)$ & $5(25 \%)$ \\
\hline & 1 child & $1(100 \%)$ & $13(68 \%)$ & $14(70 \%)$ \\
\hline & 2 children & 0 & $1(5 \%)$ & $1(5 \%)$ \\
\hline \multirow[t]{4}{*}{$\begin{array}{l}\text { Current occupation/ } \\
\text { employment status }\end{array}$} & $\begin{array}{l}\text { In school/college/university/ other } \\
\text { tertiary education }\end{array}$ & $7(32 \%)$ & $37(54 \%)$ & $44(48 \%)$ \\
\hline & In training & $3(14 \%)$ & $6(9 \%)$ & $9(10 \%)$ \\
\hline & Employed & $5(23 \%)$ & $8(11 \%)$ & $13(14 \%)$ \\
\hline & $\begin{array}{l}\text { Not in education, employment or } \\
\text { training (NEET) }\end{array}$ & 7 (32\%) & $18(26 \%)$ & $25(27 \%)$ \\
\hline \multicolumn{2}{|l|}{ Ever repeated a grade at school } & $14(64 \%)$ & $33(47 \%)$ & $47(52 \%)$ \\
\hline \multirow{3}{*}{$\begin{array}{l}\text { Days absent from school or } \\
\text { work in past month }\end{array}$} & 0 days & $13(59 \%)$ & $34(49 \%)$ & $47(52 \%)$ \\
\hline & $1-2$ days & $7(32 \%)$ & $26(38 \%)$ & $33(36 \%)$ \\
\hline & 3 or more days & $2(9 \%)$ & $9(13 \%)$ & $11(12 \%)$ \\
\hline \multicolumn{2}{|c|}{ Youth multidimensionally poor $^{2}(\mathrm{n}=88)$} & $9(41 \%)$ & $30(45 \%)$ & $39(44 \%)$ \\
\hline \multicolumn{2}{|c|}{ Educational attainment } & $4(18 \%)$ & $16(24 \%)$ & $20(22 \%)$ \\
\hline & $\begin{array}{l}\text { Aged } 17-20 \& \text { completed less than } \\
\text { nine years of schooling }\end{array}$ & $1(5 \%)$ & $2(3 \%)$ & $3(3 \%)$ \\
\hline & $\begin{array}{l}\text { Aged } 21-24 \& \text { completed less than } \\
\text { matric or equivalent }\end{array}$ & $3(14 \%)$ & $14(21 \%)$ & $17(19 \%)$ \\
\hline \multicolumn{2}{|c|}{ General health and functioning } & $16(73 \%)$ & $46(67 \%)$ & $62(68 \%)$ \\
\hline & Difficulty hearing & $3(14 \%)$ & $13(19 \%)$ & $16(18 \%)$ \\
\hline & Difficulty seeing & $7(33 \%)$ & $26(39 \%)$ & $33(38 \%)$ \\
\hline
\end{tabular}




\begin{tabular}{|c|c|c|c|c|}
\hline & Difficulty moving around & $2(10 \%)$ & $15(22 \%)$ & $17(20 \%)$ \\
\hline & Difficulty concentrating & $12(57 \%)$ & $32(48 \%)$ & $44(50 \%)$ \\
\hline & Difficulty with self-care & 0 & $14(21 \%)$ & $14(16 \%)$ \\
\hline \multicolumn{2}{|l|}{ Living environment } & $\begin{array}{l}0(0- \\
0.036)\end{array}$ & $\begin{array}{l}0.036(0- \\
0.071)\end{array}$ & $\begin{array}{l}0.036(0- \\
0.071)\end{array}$ \\
\hline & $\begin{array}{l}\text { Fuel for lighting other than } \\
\text { electricity, gas/ solar power }\end{array}$ & 0 & 1 (1\%) & 1 (1\%) \\
\hline & $\begin{array}{l}\text { Fuel for heating other than } \\
\text { electricity, gas/ solar power }\end{array}$ & $5(23 \%)$ & $21(30 \%)$ & $26(28 \%)$ \\
\hline & $\begin{array}{l}\text { Fuel for cooking other than } \\
\text { electricity or gas }\end{array}$ & 0 & 1 (1\%) & $1(1 \%)$ \\
\hline & $\begin{array}{l}\text { Sanitation: Household without a } \\
\text { flush toilet }\end{array}$ & $3(14 \%)$ & $5(7 \%)$ & $8(9 \%)$ \\
\hline & $\begin{array}{l}\text { Water: Household without piped } \\
\text { water on site }\end{array}$ & $1(5 \%)$ & $15(21 \%)$ & $16(17 \%)$ \\
\hline & $\begin{array}{l}\text { Dwelling that is an informal shack } \\
\text { /caravan/ tent/ other }\end{array}$ & $4(18 \%)$ & $28(41 \%)$ & $32(35 \%)$ \\
\hline \multicolumn{2}{|c|}{$\begin{array}{l}\text { Household assets }{ }^{3} \text { : Household with } \leq \text { two assets below } \& \\
\text { no motor vehicle }\end{array}$} & $3(14 \%)$ & $20(29 \%)$ & $23(25 \%)$ \\
\hline \multirow{7}{*}{\multicolumn{2}{|c|}{\begin{tabular}{l|l} 
& no radio \\
\cline { 2 - 2 } & no television \\
\cline { 2 - 2 } & no landline \\
\cline { 2 - 2 } & no cell phone \\
\cline { 2 - 2 } & no refrigerator \\
\cline { 2 - 2 }-64 years $)$ & no motor vehicle $(p=0.003)$ \\
\multicolumn{2}{c}{ Household adult unemployment: no employed adults $(18$}
\end{tabular}}} & $9(41 \%)$ & $32(46 \%)$ & $41(45 \%)$ \\
\hline & & $2(9 \%)$ & $6(9 \%)$ & $8(9 \%)$ \\
\hline & & $22(100 \%)$ & $67(96 \%)$ & $89(97 \%)$ \\
\hline & & $1(5 \%)$ & $14(20 \%)$ & $15(16 \%)$ \\
\hline & & $6(27 \%)$ & $24(34 \%)$ & $30(33 \%)$ \\
\hline & & $10(45 \%)$ & $55(79 \%)$ & $65(71 \%)$ \\
\hline & & $1(5 \%)$ & $13(19 \%)$ & $14(15 \%)$ \\
\hline \multicolumn{2}{|c|}{ Household Food Insecurity Access Score } & $2.5(1-5)$ & $3(0-7)$ & $3(0-7)$ \\
\hline & food secure & $4(19 \%)$ & $24(34 \%)$ & $28(30 \%)$ \\
\hline & mildly food insecure & $7(32 \%)$ & $11(16 \%)$ & $18(20 \%)$ \\
\hline & moderately food insecure & $4(19 \%)$ & $7(10 \%)$ & $11(12 \%)$ \\
\hline & severely food insecure & 7 (32\%) & $28(40 \%)$ & $35(38 \%)$ \\
\hline
\end{tabular}

1 -value shown if significant at 5\% level: $p<0.05$;

${ }^{2}$ Youth MPI poor: those with composite score $>33.3 \%$;

${ }^{3}$ Individual living in a household that does not own more than two of: radio, TV, landline, mobile phone, bike, motorbike or refrigerator AND does not own a motor car or truck 
TABLE 2: Physical Activity, Sedentary and Dietary Behaviour and Nutritional Knowledge of AYLHIV by Gender 


\begin{tabular}{|c|c|c|c|c|}
\hline $\begin{array}{l}\text { Variable: Median (IQR) or } \\
\text { n (\%) }\end{array}$ & Description & $\begin{array}{l}\text { Male: } n=19 \\
(22 \%)\end{array}$ & $\begin{array}{l}\text { Female: } n= \\
67(78 \%)\end{array}$ & $\begin{array}{l}\text { Total: } \mathrm{n} \\
=86\end{array}$ \\
\hline \multirow[t]{3}{*}{$\begin{array}{l}\text { Vigorous-intensity } \\
\text { Physical activity }\end{array}$} & $\begin{array}{l}\text { Any vigorous-intensity PA for } \geq 10 \\
\text { minutes }\end{array}$ & $11(58 \%)$ & $26(39 \%)$ & $37(43 \%)$ \\
\hline & $\begin{array}{l}\text { Time spent doing vigorous-intensity } \\
\text { PA per day in minutes }\end{array}$ & $\begin{array}{l}75(30- \\
240)\end{array}$ & $\begin{array}{l}60(30- \\
120)\end{array}$ & $\begin{array}{l}60(30- \\
120)\end{array}$ \\
\hline & $\begin{array}{l}\text { Vigorous intensity activity MET- } \\
\text { minutes/week }\end{array}$ & $\begin{array}{l}2400(1200 \\
-4320)\end{array}$ & $\begin{array}{l}1680(480- \\
3840)\end{array}$ & $\begin{array}{l}1920(720- \\
4320)\end{array}$ \\
\hline \multirow[t]{3}{*}{$\begin{array}{l}\text { Moderate-intensity } \\
\text { Physical activity }\end{array}$} & $\begin{array}{l}\text { Any moderate-intensity PA for } \geq 10 \\
\text { minutes }\end{array}$ & $15(79 \%)$ & $53(79 \%)$ & $68(79 \%)$ \\
\hline & $\begin{array}{l}\text { Time spent doing moderate- intensity } \\
\text { PA per day in mins }\end{array}$ & $\begin{array}{l}75(30- \\
120)\end{array}$ & $60(30-90)$ & $\begin{array}{l}60(30- \\
90)\end{array}$ \\
\hline & $\begin{array}{l}\text { Moderate intensity activity MET- } \\
\text { minutes/week }\end{array}$ & $\begin{array}{l}1440(480- \\
1680)\end{array}$ & $\begin{array}{l}720(480- \\
1200)\end{array}$ & $\begin{array}{l}720(480- \\
1440)\end{array}$ \\
\hline \multirow[t]{3}{*}{ Active Travel } & $\begin{array}{l}\text { Walking or cycling for } \geq 10 \text { minutes } \\
\text { continuously for travel }\end{array}$ & $16(84 \%)$ & $45(67 \%)$ & $61(71 \%)$ \\
\hline & $\begin{array}{l}\text { Time spent walking or cycling on a } \\
\text { typical day in minutes }\end{array}$ & $40(30-60)$ & $30(30-60)$ & $\begin{array}{l}35(30- \\
60)\end{array}$ \\
\hline & Walking MET-minutes/week & $\begin{array}{l}610.5(396- \\
1386)\end{array}$ & $\begin{array}{l}495(247.5- \\
990)\end{array}$ & $\begin{array}{l}528(297- \\
990)\end{array}$ \\
\hline \multicolumn{2}{|c|}{ Total physical activity MET-minutes/week } & $\begin{array}{l}2504.25 \\
(690-7146)\end{array}$ & $\begin{array}{l}1173(495- \\
2826)\end{array}$ & $\begin{array}{l}1215(495- \\
3348)\end{array}$ \\
\hline \multicolumn{2}{|c|}{$\begin{array}{l}\text { Insufficient physical activity (achieved }<600 \text { MET-minutes per } \\
\text { week) }\end{array}$} & $4(21 \%)$ & $23(34 \%)$ & 27 (31\%) \\
\hline \multicolumn{2}{|c|}{ High physical activity ( $\geq 3000$ MET minutes per week) } & $8(42 \%)$ & $15(22 \%)$ & $23(27 \%)$ \\
\hline \multicolumn{2}{|c|}{ Sedentary behaviour ( $\geq 3$ hours of sedentary time per day) } & $10(53 \%)$ & $32(48 \%)$ & $42(49 \%)$ \\
\hline \multicolumn{5}{|l|}{ Dietary Behaviour $(\mathrm{n}=82)$} \\
\hline \multirow{5}{*}{$\begin{array}{l}\text { Fruits consumption } \\
(p=0.028)\end{array}$} & Never & 0 & $2(3 \%)$ & $2(2 \%)$ \\
\hline & Once a week / less than once a week & $4(21 \%)$ & $27(43 \%)$ & $31(28 \%)$ \\
\hline & $2-4$ times a week & $5(26 \%)$ & $15(24 \%)$ & $20(24 \%)$ \\
\hline & Frequently (5 - 6 times a week) & $4(21 \%)$ & $2(3 \%)$ & $6(7 \%)$ \\
\hline & Daily or more than once daily & $6(32 \%)$ & 17 (27\%) & $23(2 \%)$ \\
\hline \multirow[t]{5}{*}{ Vegetables consumption } & Never & 0 & $4(6 \%)$ & $4(5 \%)$ \\
\hline & Once a week / less than once a week & $3(17 \%)$ & $9(14 \%)$ & $12(15 \%)$ \\
\hline & 2 - 4 times a week & $1(6 \%)$ & $9(14 \%)$ & $10(12 \%)$ \\
\hline & Frequently (5 - 6 times a week) & $6(33 \%)$ & $7(11 \%)$ & $13(16 \%)$ \\
\hline & Daily or more than once daily & $8(44 \%)$ & $34(54 \%)$ & $42(52 \%)$ \\
\hline \multirow{2}{*}{$\begin{array}{l}\text { Wholegrain bread or } \\
\text { cereal Consumption }\end{array}$} & Never & $1(5 \%)$ & $4(6 \%)$ & $5(6 \%)$ \\
\hline & Once a week / less than once a week & $5(26 \%)$ & $16(25 \%)$ & $21(26 \%)$ \\
\hline
\end{tabular}




\begin{tabular}{|c|c|c|c|c|}
\hline \multirow[t]{3}{*}{$(\mathrm{n}=68)$} & $2-4$ times a week & $2(11 \%)$ & $6(10 \%)$ & $8(10 \%)$ \\
\hline & Frequently (5 - 6 times a week) & $3(16 \%)$ & $4(6 \%)$ & $7(9 \%)$ \\
\hline & Daily or more than once daily & $5(26 \%)$ & $22(35 \%)$ & $27(33 \%)$ \\
\hline \multicolumn{2}{|c|}{ Daily consumption of sugar-sweetened beverages } & $5(26 \%)$ & $20(30 \%)$ & $25(29 \%)$ \\
\hline \multicolumn{2}{|c|}{ Daily consumption of deep-fried foods } & $3(16 \%)$ & $15(22 \%)$ & $18(21 \%)$ \\
\hline \multicolumn{2}{|c|}{ Daily consumption of fast foods } & $1(5 \%)$ & $12(18 \%)$ & $13(15 \%)$ \\
\hline \multicolumn{2}{|c|}{ Daily consumption of sweets \& cakes } & $2(11 \%)$ & $25(37 \%)$ & $27(31 \%)$ \\
\hline \multicolumn{2}{|c|}{ Ate a meal prepared outside the home in the past week } & $10(59 \%)$ & $45(73 \%)$ & $55(67 \%)$ \\
\hline & $\begin{array}{l}\text { Meals eaten outside the home in past week: }(n= \\
55)\end{array}$ & $2(1-10)$ & $2(2-3)$ & $2(2-4)$ \\
\hline \multicolumn{2}{|c|}{ Breakfast consumption: number of days in the past week } & $5(3-6)$ & $5(3-7)$ & $5(3-7)$ \\
\hline \multirow[t]{3}{*}{ Breakfast consumption } & $\begin{array}{l}\text { Skippers: ate breakfast } 0-2 \\
\text { days/week }\end{array}$ & $5(23 \%)$ & $13(20 \%)$ & $18(21 \%)$ \\
\hline & $\begin{array}{l}\text { Semi-skippers: ate breakfast } 3-4 \\
\text { days/week }\end{array}$ & $5(23 \%)$ & $13(20 \%)$ & $18(21 \%)$ \\
\hline & $\begin{array}{l}\text { Non-skippers: ate breakfast } 5 \text { - } 7 \\
\text { days/week }\end{array}$ & $12(54 \%)$ & $39(60 \%)$ & $51(58 \%)$ \\
\hline \multicolumn{2}{|c|}{$\begin{array}{l}\text { Overall General Nutrition Knowledge score percentage \% (score } \\
\text { /88) }(95 \% \mathrm{CI})\end{array}$} & $\begin{array}{l}40.3 \%(34.5 \\
-46.1)\end{array}$ & $\begin{array}{l}36.5 \%(34.0 \\
-38.9)\end{array}$ & $\begin{array}{l}37.3 \% \\
(35.1 \text { - } \\
39.6)\end{array}$ \\
\hline & $\begin{array}{l}\text { 1. Dietary recommendations } \\
\text { (score/18) }\end{array}$ & $\begin{array}{l}44.2 \%(35.3 \\
-53.0)\end{array}$ & $\begin{array}{l}42.5 \%(38.7 \\
-46.3)\end{array}$ & $\begin{array}{l}42.9 \% \\
(39.4- \\
46.4)\end{array}$ \\
\hline & 2. Food Groups (score/36) & $\begin{array}{l}40.4(35.5- \\
45.4)\end{array}$ & $\begin{array}{l}37.1(34.1- \\
40.1)\end{array}$ & $\begin{array}{l}37.9(35.3- \\
40.4)\end{array}$ \\
\hline & $\begin{array}{l}\text { 3. Healthy food choices } \\
\text { (score/13) }\end{array}$ & $\begin{array}{l}36.8(27.3- \\
46.2)\end{array}$ & $\begin{array}{l}30.5(26.0- \\
35.1)\end{array}$ & $\begin{array}{l}31.9(27.9- \\
36.0)\end{array}$ \\
\hline & $\begin{array}{l}\text { 4. Diet, disease and weight } \\
\text { management (score } / 21 \text { ) }\end{array}$ & $\begin{array}{l}36.8(28.2- \\
45.3)\end{array}$ & $\begin{array}{l}33.9(30.6- \\
37.1)\end{array}$ & $\begin{array}{l}34.5(31.4- \\
37.6)\end{array}$ \\
\hline
\end{tabular}

MET = Metabolic equivalent of task; $n=$ number; $\%=$ percentage; $P A=$ physical activity; $p$-value shown if significant at 5\% level: $p<0.05$.

TABLE 3: Physical Activity, Sedentary and Dietary Behaviour and Nutritional Knowledge by Age Group 


\begin{tabular}{|c|c|c|c|c|c|c|}
\hline $\begin{array}{l}\text { Variable: Median (IQR) } \\
\text { or } \mathrm{n}(\%)\end{array}$ & Description & $\begin{array}{l}15-17 \\
\text { years: } \\
n=11 \\
(13 \%)\end{array}$ & $\begin{array}{l}18-19 \\
\text { years: } \\
n=23 \\
(27 \%)\end{array}$ & $\begin{array}{l}20- \\
\text { 21years: } \\
\mathrm{n}=23 \\
(27 \%)\end{array}$ & $\begin{array}{l}22-24 \\
\text { years: } n= \\
29(34 \%)\end{array}$ & $\begin{array}{l}\text { Total: } \\
\mathrm{n}=86\end{array}$ \\
\hline \multirow[t]{3}{*}{$\begin{array}{l}\text { Vigorous intensity } \\
\text { Physical Activity }\end{array}$} & $\begin{array}{l}\text { Prevalence of PA for } \\
\geq 10 \text { mins }\end{array}$ & $8(80 \%)$ & $9(39 \%)$ & $11(50 \%)$ & $9(31 \%)$ & $\begin{array}{l}37 \\
(43 \%)\end{array}$ \\
\hline & $\begin{array}{l}\text { Time spent per day in } \\
\text { minutes }\end{array}$ & $\begin{array}{l}120(30 \\
-240)\end{array}$ & $\begin{array}{l}90(30- \\
120)\end{array}$ & $\begin{array}{l}105(30- \\
180)\end{array}$ & $60(30-60)$ & $\begin{array}{l}60(30- \\
120)\end{array}$ \\
\hline & MET-minutes/week & $\begin{array}{l}4800 \\
(720- \\
9600)\end{array}$ & $\begin{array}{l}2160 \\
(1200- \\
2400)\end{array}$ & $\begin{array}{l}2520(960- \\
4320)\end{array}$ & $\begin{array}{l}1440(480- \\
1920)\end{array}$ & $\begin{array}{l}1920 \\
(720- \\
4320)\end{array}$ \\
\hline \multirow{3}{*}{$\begin{array}{l}\text { Moderate- } \\
\text { intensity Physical } \\
\text { Activity }\end{array}$} & $\begin{array}{l}\text { Prevalence of PA for } \\
\geq 10 \text { minutes }\end{array}$ & $5(50 \%)$ & $\begin{array}{l}17 \\
(74 \%)\end{array}$ & $19(86 \%)$ & $25(86 \%)$ & $\begin{array}{l}68 \\
(79 \%) \\
\end{array}$ \\
\hline & $\begin{array}{l}\text { Time spent per day in } \\
\text { mins }\end{array}$ & $\begin{array}{l}60(30- \\
60)\end{array}$ & $\begin{array}{l}60(40- \\
120)\end{array}$ & $\begin{array}{l}30(30- \\
120)\end{array}$ & $30(30-60)$ & $\begin{array}{l}60(30- \\
90)\end{array}$ \\
\hline & MET-minutes/week & $\begin{array}{l}720 \\
(360- \\
720)\end{array}$ & $\begin{array}{l}1440 \\
(640- \\
1680)\end{array}$ & $\begin{array}{l}600(420- \\
1680)\end{array}$ & $\begin{array}{l}600(480- \\
840)\end{array}$ & $\begin{array}{l}720 \\
(480- \\
1440)\end{array}$ \\
\hline \multirow[t]{3}{*}{$\begin{array}{l}\text { Active Travel } \\
\text { Walking or cycling }\end{array}$} & $\begin{array}{l}\text { Walking or cycling for } \\
\geq 10 \text { minutes }\end{array}$ & $7(70 \%)$ & $\begin{array}{l}19 \\
(83 \%)\end{array}$ & $14(64 \%)$ & $20(69 \%)$ & $\begin{array}{l}60 \\
(71 \%) \\
\end{array}$ \\
\hline & $\begin{array}{l}\text { Time spent daily in } \\
\text { mins }\end{array}$ & $\begin{array}{l}30(30- \\
120)\end{array}$ & $\begin{array}{l}30(30- \\
60)\end{array}$ & $\begin{array}{l}60(30- \\
60)\end{array}$ & $\begin{array}{l}30(30- \\
60)\end{array}$ & $\begin{array}{l}35(30- \\
60)\end{array}$ \\
\hline & $\begin{array}{l}\text { Walking MET- } \\
\text { minutes/week }\end{array}$ & $\begin{array}{l}495 \\
(495- \\
495)\end{array}$ & $\begin{array}{l}693 \\
(396- \\
1386)\end{array}$ & $\begin{array}{l}742.5(495 \\
-1188)\end{array}$ & $\begin{array}{l}495(198- \\
693)\end{array}$ & $\begin{array}{l}528 \\
(297- \\
990)\end{array}$ \\
\hline \multicolumn{2}{|c|}{ Total physical activity MET-minutes/week } & $\begin{array}{l}984 \\
(280- \\
5295)\end{array}$ & $\begin{array}{l}2160 \\
(800- \\
3756)\end{array}$ & $\begin{array}{l}1638.75 \\
(420- \\
6624)\end{array}$ & $\begin{array}{l}876(508.5 \\
-1878)\end{array}$ & $\begin{array}{l}1215 \\
(495- \\
3348)\end{array}$ \\
\hline \multicolumn{2}{|c|}{$\begin{array}{l}\text { Insufficient physical activity ( }<600 \text { MET-mins } \\
\text { per week) }\end{array}$} & $5(45 \%)$ & $5(22 \%)$ & $7(30 \%)$ & $10(34 \%)$ & $\begin{array}{l}27 \\
(31 \%)\end{array}$ \\
\hline \multicolumn{2}{|c|}{$\begin{array}{l}\text { High physical activity ( } \geq 3000 \text { MET mins per } \\
\text { week) }\end{array}$} & $3(27 \%)$ & $8(35 \%)$ & $9(39 \%)$ & $3(10 \%)$ & $\begin{array}{l}23 \\
(27 \%) \\
\end{array}$ \\
\hline \multicolumn{2}{|c|}{$\begin{array}{l}\text { Sedentary behaviour ( } \geq 3 \text { hours of sedentary } \\
\text { time per day) }\end{array}$} & 7 (70\%) & $9(39 \%)$ & $12(54 \%)$ & $14(49 \%)$ & $\begin{array}{l}42 \\
(49 \%)\end{array}$ \\
\hline \multicolumn{7}{|l|}{ Dietary Behaviour $(\mathrm{n}=82)$} \\
\hline \multirow[t]{3}{*}{ Fruits consumption } & Never & 0 & 0 & 0 & $2(7 \%)$ & $2(2 \%)$ \\
\hline & $\begin{array}{l}\text { Once a week / less } \\
\text { than once a week }\end{array}$ & $5(50 \%)$ & 9 (39\%) & $10(45 \%)$ & 7 (26\%) & $\begin{array}{l}31 \\
(38 \%)\end{array}$ \\
\hline & $2-4$ times a week & $2(20 \%)$ & $5(22 \%)$ & $4(18 \%)$ & $9(33 \%)$ & 20 \\
\hline
\end{tabular}




\begin{tabular}{|c|c|c|c|c|c|c|}
\hline & & & & & & $(24 \%)$ \\
\hline & $\begin{array}{l}\text { Frequently ( } 5 \text { - } 6 \\
\text { times a week) }\end{array}$ & $2(20 \%)$ & 0 & $3(14 \%)$ & $1(4 \%)$ & $6(7 \%)$ \\
\hline & $\begin{array}{l}\text { Daily or more than } \\
\text { once daily }\end{array}$ & $1(10 \%)$ & $9(39 \%)$ & $5(23 \%)$ & $8(30 \%)$ & $\begin{array}{l}23 \\
(28 \%)\end{array}$ \\
\hline \multirow{5}{*}{$\begin{array}{l}\text { Vegetables } \\
\text { consumption }\end{array}$} & Never & 0 & $1(4 \%)$ & $1(5 \%)$ & $2(7 \%)$ & $4(5 \%)$ \\
\hline & $\begin{array}{l}\text { Once a week / less } \\
\text { than once a week }\end{array}$ & $2(20 \%)$ & $5(22 \%)$ & $3(14 \%)$ & $2(7 \%)$ & $\begin{array}{l}12 \\
(15 \%)\end{array}$ \\
\hline & 2 - 4 times a week & $2(20 \%)$ & $1(4 \%)$ & 0 & 7 (265) & $\begin{array}{l}10 \\
(12 \%)\end{array}$ \\
\hline & $\begin{array}{l}\text { Frequently ( } 5 \text { - } 6 \\
\text { times a week) }\end{array}$ & $2(20 \%)$ & $4(17 \%)$ & $6(29 \%)$ & $1(4 \%)$ & $\begin{array}{l}13 \\
(16 \%)\end{array}$ \\
\hline & $\begin{array}{l}\text { Daily or more than } \\
\text { once daily }\end{array}$ & $4(40 \%)$ & $\begin{array}{l}12 \\
(52 \%)\end{array}$ & $11(52 \%)$ & $15(56 \%)$ & $\begin{array}{l}42 \\
(52 \%)\end{array}$ \\
\hline \multirow{5}{*}{$\begin{array}{l}\text { Whole-grain bread or } \\
\text { cereal consumption } \\
(\mathrm{n}=68)\end{array}$} & Never & 0 & $1(4 \%)$ & $1(5 \%)$ & $3(11 \%)$ & $5(6 \%)$ \\
\hline & $\begin{array}{l}\text { Once a week / less } \\
\text { than once a week }\end{array}$ & $5(50 \%)$ & $7(30 \%)$ & $5(23 \%)$ & $4(15 \%)$ & $\begin{array}{l}21 \\
(26 \%)\end{array}$ \\
\hline & $2-4$ times a week & $2(20 \%)$ & $1(4 \%)$ & $1(5 \%)$ & $4(15 \%)$ & $8(10 \%)$ \\
\hline & $\begin{array}{l}\text { Frequently (5 - } 6 \\
\text { times a week) }\end{array}$ & $1(10 \%)$ & $4(17 \%)$ & $1(5 \%)$ & $1(4 \%)$ & $7(9 \%)$ \\
\hline & $\begin{array}{l}\text { Daily or more than } \\
\text { once daily }\end{array}$ & $1(10 \%)$ & 9 (39\%) & $7(32 \%)$ & $10(37 \%)$ & $\begin{array}{l}27 \\
(33 \%)\end{array}$ \\
\hline \multicolumn{2}{|c|}{$\begin{array}{l}\text { Daily consumption of sugar-sweetened } \\
\text { beverages }\end{array}$} & $3(27 \%)$ & $6(26 \%)$ & $9(39 \%)$ & 7 (24\%) & $\begin{array}{l}25 \\
(29 \%)\end{array}$ \\
\hline \multicolumn{2}{|c|}{$\begin{array}{l}\text { Daily consumption of deep-fried foods ( } p= \\
0.031 \text { ) }\end{array}$} & $1(9 \%)$ & $8(35 \%)$ & $5(22 \%)$ & $4(14 \%)$ & $\begin{array}{l}18 \\
(21 \%) \\
\end{array}$ \\
\hline \multicolumn{2}{|c|}{ Daily consumption of fast foods } & $2(18 \%)$ & $6(26 \%)$ & $2(9 \%)$ & $3(10 \%)$ & $\begin{array}{l}13 \\
(15 \%)\end{array}$ \\
\hline \multicolumn{2}{|c|}{ Daily consumption of sweets \& cakes } & $4(36 \%)$ & $9(39 \%)$ & $6(26 \%)$ & $8(28 \%)$ & $\begin{array}{l}27 \\
(31 \%)\end{array}$ \\
\hline \multicolumn{7}{|c|}{ Dietary Behaviour $(\mathrm{n}=82)$} \\
\hline \multicolumn{2}{|c|}{$\begin{array}{l}\text { Ate meal prepared outside the home in past } \\
\text { week }\end{array}$} & $5(50 \%)$ & $\begin{array}{l}14 \\
(64 \%)\end{array}$ & $15(68 \%)$ & $21(78 \%)$ & $\begin{array}{l}55 \\
(67 \%)\end{array}$ \\
\hline & $\begin{array}{l}\text { als eaten outside the } \\
\text { me in past week: }(n=\end{array}$ & $\begin{array}{l}2(1- \\
3)\end{array}$ & $\begin{array}{l}2(2- \\
4)\end{array}$ & $2(2-4)$ & $2(2-3)$ & $\begin{array}{l}2(2- \\
4)\end{array}$ \\
\hline \multirow[t]{2}{*}{$\begin{array}{l}\text { Breakfast } \\
\text { consumption }\end{array}$} & $\begin{array}{l}\text { ippers: ate breakfast } 0 \\
\text { days/week }\end{array}$ & $2(20 \%)$ & $7(30 \%)$ & $3(14 \%)$ & $7(26 \%)$ & $\begin{array}{l}19 \\
(23 \%)\end{array}$ \\
\hline & mi-skippers: ate & $1(10 \%)$ & $4(17 \%)$ & $6(27 \%)$ & $3(11 \%)$ & 14 \\
\hline
\end{tabular}




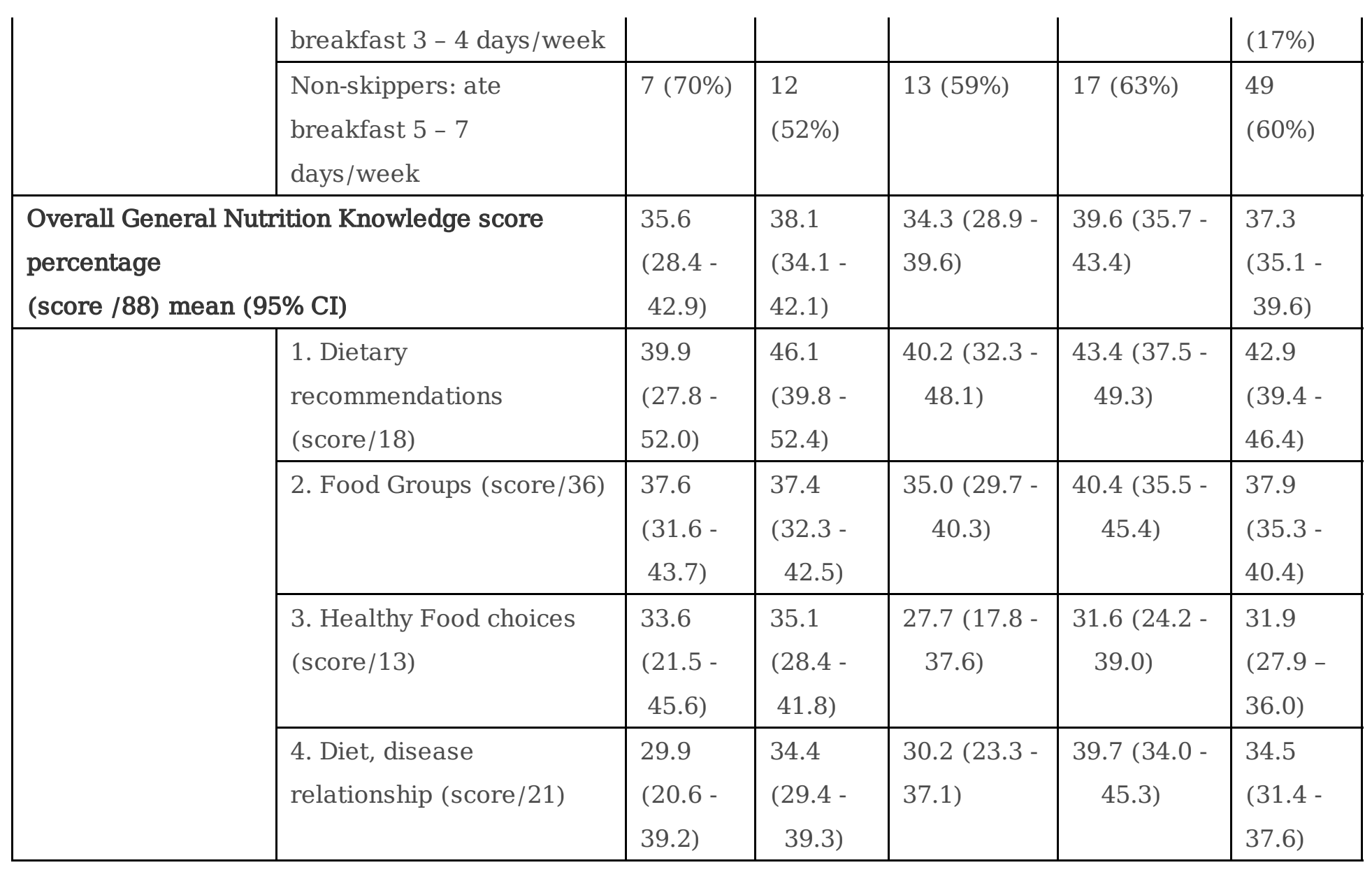

$n=$ number $\%=$ percentage $;$ mins $=$ minutes $; P A=$ physical activity $;$ MET $=$ Metabolic equivalent of task;

p-value from Kruskal Wallis test shown if significant at 5\% level: $p<0.05$.

TABLE 4: Comorbidities and Pre-existing diagnoses by Gender 


\begin{tabular}{|c|c|c|c|c|c|}
\hline \multicolumn{2}{|c|}{$\begin{array}{l}\text { Variable: median (IQR) or } \mathrm{n}(\%) \text { or proportion } \\
{[95 \% \mathrm{CI}]}\end{array}$} & Male: $\mathrm{n}=22$ & Female: $n=70$ & Total $\mathrm{n}=92$ & $\begin{array}{l}\mathrm{p}- \\
\text { value }^{1}\end{array}$ \\
\hline \multicolumn{2}{|c|}{$\begin{array}{l}\text { Self-reported pre-existing diagnosis: prop [95\% } \\
\mathrm{CI}]^{2}\end{array}$} & $\begin{array}{l}0.45[0.24- \\
0.68]\end{array}$ & $\begin{array}{l}0.31[0.21- \\
0.44]\end{array}$ & $\begin{array}{l}0.35[0.25- \\
0.45]\end{array}$ & 0.228 \\
\hline & Tuberculosis & $\begin{array}{l}0.32[0.14- \\
0.55]\end{array}$ & $0.2[0.11-0.31]$ & $\begin{array}{l}0.23[0.15- \\
0.33]\end{array}$ & 0.229 \\
\hline & Depression or Anxiety & $\begin{array}{l}0.14[0.029- \\
0.35]\end{array}$ & $\begin{array}{l}0.071[0.024- \\
0.16]\end{array}$ & $\begin{array}{l}0.087[0.038- \\
0.16]\end{array}$ & 0.332 \\
\hline & Asthma & $\begin{array}{l}0.045[0.0012- \\
0.23]\end{array}$ & $\begin{array}{l}0.043[0.0089- \\
0.12]\end{array}$ & $\begin{array}{l}0.043[0.012- \\
0.11]\end{array}$ & 0.946 \\
\hline & High Blood Pressure & $0[0-0.15]$ & $\begin{array}{l}0.043[0.089- \\
0.12]\end{array}$ & $\begin{array}{l}0.033[0.0068- \\
0.092]\end{array}$ & 0.327 \\
\hline & Diabetes & $0[0-0.15]$ & $\begin{array}{l}0.014[0.00036 \\
-0.077]\end{array}$ & $\begin{array}{l}0.011[0.00028 \\
-0.061]\end{array}$ & 0.576 \\
\hline \multicolumn{2}{|c|}{$\begin{array}{l}\text { Respiratory Symptoms over past } 3 \text { months }(n= \\
\text { 89): prop }[95 \% \text { CI] }\end{array}$} & $\begin{array}{l}0.10[0.012- \\
0.30]\end{array}$ & $\begin{array}{l}0.13[0.062- \\
0.24]\end{array}$ & $\begin{array}{l}0.12[0.063- \\
0.21]\end{array}$ & 0.651 \\
\hline \multicolumn{2}{|c|}{$\begin{array}{l}\text { Diabetes Symptoms over past } 3 \text { months: prop } \\
{[95 \% \mathrm{CI}]}\end{array}$} & $\begin{array}{l}0.29[0.11- \\
0.52]\end{array}$ & $\begin{array}{l}0.24[0.14- \\
0.35]\end{array}$ & $\begin{array}{l}0.25[0.16- \\
0.35]\end{array}$ & 0.640 \\
\hline \multicolumn{2}{|c|}{ Family history of diabetes: prop [95\% CI] } & $\begin{array}{l}0.38[0.18- \\
0.62]\end{array}$ & $\begin{array}{l}0.24[0.14- \\
0.35]\end{array}$ & $\begin{array}{l}0.27[0.18- \\
0.37]\end{array}$ & 0.189 \\
\hline \multicolumn{2}{|c|}{$\begin{array}{l}\text { Random Blood Glucose in } \\
\mathrm{mmol} / \mathrm{l}(\mathrm{n}=31)^{3} \text { median (IQR) }\end{array}$} & $3.7(0.75-4.95)$ & $4.8(4.0-5.5)$ & $4.7(3.1-5.3)$ & 0.1672 \\
\hline \multicolumn{2}{|c|}{$\begin{array}{l}\text { CESD-10 Depression Score }(\mathrm{n}=82) \text { median } \\
(\mathrm{IQR})\end{array}$} & $8(4-9)$ & $10(6-14)$ & $9(6-14)$ & 0.055 \\
\hline & $\begin{array}{l}\text { Significant depression } \\
(\mathrm{CESD} \geq 10): \text { prop }[95 \% \mathrm{CI}]\end{array}$ & $\begin{array}{l}0.19[0.054- \\
0.42]\end{array}$ & $\begin{array}{l}0.51[0.38- \\
0.64]\end{array}$ & $\begin{array}{l}0.43[0.32- \\
0.54]\end{array}$ & 0.011 \\
\hline \multicolumn{2}{|c|}{$\begin{array}{l}\text { Kessler Psychological Distress Score (K10) } \\
(\mathrm{n}=85) \text { median (IQR) }\end{array}$} & $17(13-23)$ & $19(13-25)$ & $19(13-25)$ & 0.959 \\
\hline \multirow{4}{*}{$\begin{array}{l}\text { Categories } \\
\text { n (\%) }\end{array}$} & Mentally well $($ K10 <20) & $12(57 \%)$ & 35 (55\%) & $47(55 \%)$ & \multirow[t]{4}{*}{0.407} \\
\hline & Mild distress (K10 20-24) & $4(19 \%)$ & $10(16 \%)$ & $14(16 \%)$ & \\
\hline & Moderate distress (K10 25-29) & $2(10 \%)$ & $15(23 \%)$ & $17(20 \%)$ & \\
\hline & Severe distress $(\mathrm{K} 10 \geq 30)$ & $3(14 \%)$ & $4(6 \%)$ & $7(8 \%)$ & \\
\hline \multicolumn{6}{|c|}{ Measured Clinical Signs } \\
\hline \multicolumn{2}{|c|}{$\mathrm{BMI}$ in $\mathrm{kg} / \mathrm{m}^{2} ;$ median (IQR) } & $\begin{array}{l}21.0(19.1- \\
22.6)\end{array}$ & $\begin{array}{l}23.3(20.2- \\
27.2)\end{array}$ & $\begin{array}{l}22.8(19.9- \\
26.2)\end{array}$ & 0.0102 \\
\hline \multirow{4}{*}{$\begin{array}{l}\text { Categories } \\
\text { n (\%) }\end{array}$} & Underweight $(\mathrm{BMI}<18.5)$ & $5(23 \%)$ & $5(7 \%)$ & $10(11 \%)$ & \multirow[t]{4}{*}{0.032} \\
\hline & Normal weight $(18.5 \leq \mathrm{BMI}<25)$ & $14(64 \%)$ & $33(49 \%)$ & $47(53 \%)$ & \\
\hline & Overweight $(25 \leq \mathrm{BMI}<30)$ & $3(14 \%)$ & $19(28 \%)$ & $22(25 \%)$ & \\
\hline & Obese (BMI $\geq 30$ ) & 0 & $10(15 \%)$ & $10(11 \%)$ & \\
\hline
\end{tabular}




\begin{tabular}{|c|c|c|c|c|c|}
\hline \multicolumn{2}{|c|}{$\begin{array}{l}\text { Waist circumference (WC) in cm; median } \\
\text { (IQR) }\end{array}$} & $74(71.5-81.0)$ & $\begin{array}{l}78.4(71.5- \\
88.0)\end{array}$ & $76(71.5-87)$ & 0.2135 \\
\hline & Abdominal obesity ${ }^{4}$ & $1(5 \%)$ & $17(24 \%)$ & $18(20 \%)$ & 0.049 \\
\hline \multicolumn{2}{|c|}{ Hip circumference in cm; median (IQR) } & $87.5(84-94)$ & $\begin{array}{l}97.5(90.5- \\
108)\end{array}$ & $\begin{array}{l}95(86.75- \\
106.5)\end{array}$ & 0.0011 \\
\hline \multicolumn{2}{|c|}{ Waist-hip ratio (WHR) median (IQR) } & $\begin{array}{l}0.85(0.82- \\
0.87)\end{array}$ & $\begin{array}{l}0.82(0.77- \\
0.85)\end{array}$ & $\begin{array}{l}0.82(0.78- \\
0.87)\end{array}$ & 0.0265 \\
\hline \multicolumn{2}{|c|}{ Waist-to-height ratio (WHtR) median (IQR) } & $\begin{array}{l}0.43(0.42- \\
0.48)\end{array}$ & $\begin{array}{l}0.49(0.45- \\
0.56)\end{array}$ & $\begin{array}{l}0.48(0.44- \\
0.54)\end{array}$ & 0.0006 \\
\hline \multirow[t]{2}{*}{$\begin{array}{l}\text { Central } \\
\text { obesity }\end{array}$} & $\begin{array}{l}\text { WHR }>0.85 \text { in females and }> \\
0.95 \text { in males }\end{array}$ & 0 & $19(27 \%)$ & $19(21 \%)$ & 0.007 \\
\hline & WHtR $>0.5$ & $3(14 \%)$ & $31(44 \%)$ & $34(37 \%)$ & 0.020 \\
\hline \multicolumn{2}{|c|}{$\begin{array}{l}\text { Blood Pressure in mmHg } \\
\text { (Systolic/ Diastolic Blood Pressure) median } \\
\text { (IQR) }\end{array}$} & $\begin{array}{l}119.5 / 74.75 \\
(110 / 66.5- \\
131.5 / 80.5)\end{array}$ & $\begin{array}{l}115 / 74 \\
(109.5 / 68.5- \\
124.5 / 78)\end{array}$ & $\begin{array}{l}117.5 / 74.25 \\
(109.5 / 68- \\
125.5 / 79)\end{array}$ & $\begin{array}{l}0.9635 \\
0.2097\end{array}$ \\
\hline \multirow[t]{3}{*}{$\begin{array}{l}\text { Categories } \\
\mathrm{n}(\%)\end{array}$} & $\begin{array}{l}\text { Normal BP: SBP }<130 \& \text { DBP }< \\
85\end{array}$ & $13(59 \%)$ & $56(80 \%)$ & $69(75 \%)$ & \multirow[t]{3}{*}{0.056} \\
\hline & $\begin{array}{l}\text { Elevated BP: SBP 130-139 or } \\
\text { DBP } 85-89\end{array}$ & $6(27 \%)$ & $12(17 \%)$ & $18(20 \%)$ & \\
\hline & $\begin{array}{l}\text { Hypertension: SBP 140-159/ } \\
\text { DBP } 90 \text { - } 99\end{array}$ & $3(14 \%)$ & $2(3 \%)$ & $5(5 \%)$ & \\
\hline
\end{tabular}

1 Wilcoxon rank-sum test p-value for continuous variables and Pearson $\square^{2}$ test for categorical variables;

2 Proportion and Binomial exact 95\% Confidence interval;

3 Blood glucose measured only if had one or more symptoms of diabetes and OR family history; 4 Abdominal obesity: $W C>88 \mathrm{~cm}$ in females, $W C>102 \mathrm{~cm}$ in males.

TABLE 5: Comorbidities and Pre-existing diagnoses by Age Group 


\begin{tabular}{|c|c|c|c|c|c|c|c|}
\hline \multicolumn{3}{|c|}{ Variable: median (IQR) or n (\%) } & $\begin{array}{l}15-17 \\
\text { years: } \\
n=14 \\
(15 \%)\end{array}$ & $\begin{array}{l}18-19 \\
\text { years: } \\
n=23 \\
(25 \%)\end{array}$ & $\begin{array}{l}20-21 \\
\text { years: } \\
n=26 \\
(28 \%)\end{array}$ & $\begin{array}{l}22-24 \\
\text { years: } \\
n=29 \\
(32 \%)\end{array}$ & $\begin{array}{l}\text { Total: } \\
\mathrm{n}=92\end{array}$ \\
\hline \multicolumn{2}{|c|}{$\begin{array}{l}\text { Self-reported past diagnosis: } \\
\text { n (\%) }\end{array}$} & \multicolumn{2}{|l|}{$1(7 \%)$} & 9 (39\%) & 9 (35\%) & $13(45 \%)$ & 32 (35\%) \\
\hline & \multicolumn{2}{|l|}{ Tuberculosis } & $1(7 \%)$ & $5(22 \%)$ & $6(23 \%)$ & $9(31 \%)$ & $21(23 \%)$ \\
\hline & \multicolumn{2}{|c|}{ Depression or Anxiety } & 0 & $4(17 \%)$ & $2(8 \%)$ & $2(7 \%)$ & $8(9 \%)$ \\
\hline & \multicolumn{2}{|l|}{ Asthma } & 0 & $2(9 \%)$ & $2(8 \%)$ & 0 & $4(4 \%)$ \\
\hline & \multicolumn{2}{|c|}{ High Blood Pressure } & 0 & 0 & $1(4 \%)$ & $2(7 \%)$ & $3(3 \%)$ \\
\hline & \multicolumn{2}{|l|}{ Diabetes } & 0 & $1(11 \%)$ & 0 & 0 & $1(3 \%)$ \\
\hline \multicolumn{3}{|c|}{$\begin{array}{l}\text { Respiratory Symptoms over the past } 3 \\
\text { months }(n=89)\end{array}$} & $4(29 \%)$ & $4(17 \%)$ & $2(8 \%)$ & $1(3 \%)$ & $11(12 \%)$ \\
\hline \multicolumn{3}{|c|}{$\begin{array}{l}\text { Diabetes Symptoms over past } 3 \text { months ( } p= \\
0.047)^{1}\end{array}$} & $6(46 \%)$ & $8(35 \%)$ & $4(16 \%)$ & $4(14 \%)$ & $23(25 \%)$ \\
\hline \multicolumn{3}{|c|}{ Family history of diabetes } & $6(46 \%)$ & $7(30 \%)$ & $4(16 \%)$ & $7(24 \%)$ & $24(27 \%)$ \\
\hline \multicolumn{3}{|c|}{$\begin{array}{l}\text { Random Blood Glucose in } \\
\text { mmol/l }(\mathrm{n}=31)^{2} \text { median (IQR) }\end{array}$} & $\begin{array}{l}3.65(1- \\
4.9)\end{array}$ & $\begin{array}{l}4.4(2.75- \\
5.5)\end{array}$ & $\begin{array}{l}5(2.4- \\
5.45)\end{array}$ & $\begin{array}{l}5.2(4.7- \\
5.5)\end{array}$ & $\begin{array}{l}4.7(3.1- \\
5.3)\end{array}$ \\
\hline \multicolumn{3}{|c|}{$\begin{array}{l}\text { CESD-10 Depression Score }(\mathrm{n}=81 \text { ) median } \\
(\mathrm{IQR})\end{array}$} & $9(6-12)$ & $\begin{array}{l}10.5(7.5- \\
14)\end{array}$ & $\begin{array}{l}9(7.5- \\
13.5)\end{array}$ & $\begin{array}{l}8.5(6- \\
12)\end{array}$ & $9(6-14)$ \\
\hline & \multicolumn{2}{|c|}{$\begin{array}{l}\text { Significant depression } \\
(\mathrm{CESD} \geq 10)\end{array}$} & $5(38 \%)$ & $12(60 \%)$ & $8(33 \%)$ & $10(42 \%)$ & $35(43 \%)$ \\
\hline \multicolumn{3}{|c|}{$\begin{array}{l}\text { Kessler Distress Score }(\mathrm{K} 10)(\mathrm{n}=85) \\
\text { median (IQR) }\end{array}$} & $\begin{array}{l}15(14- \\
24)\end{array}$ & $\begin{array}{l}19(15- \\
25)\end{array}$ & $\begin{array}{l}18(12- \\
25)\end{array}$ & $\begin{array}{l}18.5(13- \\
25)\end{array}$ & $\begin{array}{l}19(13- \\
25)\end{array}$ \\
\hline \multirow{4}{*}{$\begin{array}{l}\text { Categories } \\
\text { n (\%) }\end{array}$} & \multicolumn{2}{|c|}{ Mentally well $(\mathrm{K} 10<20)$} & $7(54 \%)$ & $12(55 \%)$ & $13(54 \%)$ & $15(58 \%)$ & 47 (55\%) \\
\hline & \multicolumn{2}{|c|}{ Mild distress (K10 20-24) } & $3(23 \%)$ & $3(14 \%)$ & $5(21 \%)$ & $3(12 \%)$ & $14(16 \%)$ \\
\hline & \multicolumn{2}{|c|}{$\begin{array}{l}\text { Moderate distress (K10 25- } \\
\text { 29) }\end{array}$} & $1(8 \%)$ & $5(23 \%)$ & $4(17 \%)$ & $7(27 \%)$ & $17(20 \%)$ \\
\hline & \multicolumn{2}{|c|}{ Severe distress $(\mathrm{K} 10 \geq 30)$} & $2(15 \%)$ & $2(9 \%)$ & $2(8 \%)$ & $1(4 \%)$ & $7(8 \%)$ \\
\hline \multicolumn{8}{|c|}{ Measured Clinical Signs } \\
\hline \multicolumn{3}{|c|}{$\mathrm{BMI}$ in $\mathrm{kg} / \mathrm{m}^{2}(\mathrm{n}=87)$; median (IQR) } & $\begin{array}{l}20.8(19.5 \\
-24.1)\end{array}$ & $\begin{array}{l}23.2(19.3 \\
-26.4)\end{array}$ & $\begin{array}{l}22.1(20.6 \\
-25.9)\end{array}$ & $\begin{array}{l}24.2(20.2 \\
-27.1)\end{array}$ & $\begin{array}{l}22.8(19.9 \\
-26.2)\end{array}$ \\
\hline \multirow{4}{*}{$\begin{array}{l}\text { Categories } \\
\text { n (\%) }\end{array}$} & \multicolumn{2}{|c|}{ Underweight (BMI<18.5) } & $2(14 \%)$ & $4(19 \%)$ & $1(4 \%)$ & $3(10 \%)$ & $10(11 \%)$ \\
\hline & \multicolumn{2}{|c|}{$\begin{array}{l}\text { Normal weight }(18.5 \leq \mathrm{BMI}< \\
25)\end{array}$} & $9(64 \%)$ & $8(38 \%)$ & $15(60 \%)$ & $15(52 \%)$ & $47(53 \%)$ \\
\hline & \multicolumn{2}{|c|}{ Overweight $(25 \leq \mathrm{BMI}<30)$} & $1(7 \%)$ & 7 (33\%) & $6(24 \%)$ & $8(28 \%)$ & $22(25 \%)$ \\
\hline & \multicolumn{2}{|c|}{ Obese (BMI $\geq 30)$} & $2(14 \%)$ & $2(10 \%)$ & $3(12 \%)$ & $3(10 \%)$ & $10(11 \%)$ \\
\hline \multicolumn{3}{|c|}{ Waist circumference (WC) in cm; median } & $74.5(71-$ & $74.6(67.5$ & $78.8(73-$ & $79(71-$ & $76(71.5-$ \\
\hline
\end{tabular}




\begin{tabular}{|c|c|c|c|c|c|c|}
\hline \multicolumn{2}{|l|}{ (IQR) } & 76) & $-88)$ & 85) & 88) & 87) \\
\hline & Abdominal obesity ${ }^{3}$ & $2(15 \%)$ & $5(23 \%)$ & $4(12 \%)$ & $7(24 \%)$ & $17(19 \%)$ \\
\hline \multicolumn{2}{|c|}{ Hip circumference in cm; median (IQR) } & $\begin{array}{l}91(83.5- \\
104)\end{array}$ & $\begin{array}{l}90.5(84.8 \\
-107)\end{array}$ & $\begin{array}{l}96.7(93- \\
107)\end{array}$ & $\begin{array}{l}95(90- \\
105)\end{array}$ & $\begin{array}{l}95(86.5- \\
106)\end{array}$ \\
\hline \multicolumn{2}{|c|}{ Waist-hip ratio (WHR); median (IQR) } & $\begin{array}{l}0.83(0.79 \\
-0.87)\end{array}$ & $\begin{array}{l}0.83(0.77 \\
-0.87)\end{array}$ & $\begin{array}{l}0.82(0.78 \\
-0.85)\end{array}$ & $\begin{array}{l}0.82(0.79 \\
-0.87)\end{array}$ & $\begin{array}{l}0.82(0.78 \\
-0.87)\end{array}$ \\
\hline \multicolumn{2}{|c|}{ Waist-to-height ratio (WHtR); median (IQR) } & $\begin{array}{l}0.47(0.43 \\
-0.48)\end{array}$ & $\begin{array}{l}0.45(0.43 \\
-0.53)\end{array}$ & $\begin{array}{l}0.48(0.44 \\
-0.52)\end{array}$ & $\begin{array}{l}0.49(0.44 \\
-0.57)\end{array}$ & $\begin{array}{l}0.48(0.44 \\
-0.54)\end{array}$ \\
\hline \multirow[t]{2}{*}{ Central obesity } & $\begin{array}{l}\text { WHR > } 0.85 \text { in female and } \\
>0.95 \text { in male }\end{array}$ & $3(23 \%)$ & $5(23 \%)$ & $3(8 \%)$ & $8(28 \%)$ & $18(20 \%)$ \\
\hline & WHtR $>0.5$ & $2(14 \%)$ & $9(39 \%)$ & $11(42 \%)$ & $12(41 \%)$ & $34(37 \%)$ \\
\hline \multicolumn{2}{|c|}{$\begin{array}{l}\text { Systolic Blood Pressure in mmHg; median } \\
\text { (IQR) }\end{array}$} & $\begin{array}{l}117.5 \\
(112- \\
125.5)\end{array}$ & $\begin{array}{l}118 \\
(108.5- \\
124.5)\end{array}$ & $\begin{array}{l}118 \\
(111- \\
131)\end{array}$ & $\begin{array}{l}117 \\
(107.5- \\
123.5)\end{array}$ & $\begin{array}{l}117.5 \\
(109.5- \\
125.5)\end{array}$ \\
\hline \multicolumn{2}{|c|}{$\begin{array}{l}\text { Diastolic Blood Pressure in mmHg; median } \\
\text { (IQR) }\end{array}$} & $\begin{array}{l}73.5(66.5 \\
-77)\end{array}$ & $\begin{array}{l}75(67- \\
76.5)\end{array}$ & $\begin{array}{l}76(71- \\
80)\end{array}$ & $\begin{array}{l}74(68.5- \\
80)\end{array}$ & $\begin{array}{l}74.25(68 \\
-79.5)\end{array}$ \\
\hline \multirow[t]{3}{*}{$\begin{array}{l}\text { Categories } \\
\mathrm{n}(\%)\end{array}$} & $\begin{array}{l}\text { Normal BP: SBP }<130 \& \\
\mathrm{DBP}<85\end{array}$ & $11(79 \%)$ & $18(78 \%)$ & $18(69 \%)$ & $22(76 \%)$ & $69(75 \%)$ \\
\hline & $\begin{array}{l}\text { Elevated BP: SBP 130-139 or } \\
\text { DBP } 85-89\end{array}$ & $3(21 \%)$ & $4(17 \%)$ & $6(23 \%)$ & $5(17 \%)$ & $18(20 \%)$ \\
\hline & $\begin{array}{l}\text { Hypertension: SBP 140-159/ } \\
\text { DBP 90- } 99\end{array}$ & 0 & $1(4 \%)$ & $2(8 \%)$ & $2(7 \%)$ & $5(5 \%)$ \\
\hline
\end{tabular}

1 P-value derived from Fisher's exact text;

2 Blood glucose measured only if had one or more symptoms of diabetes and OR family history;

3 Abdominal obesity: $W C>88 \mathrm{~cm}$ female, $W C>102 \mathrm{~cm}$ in male.

Figures 


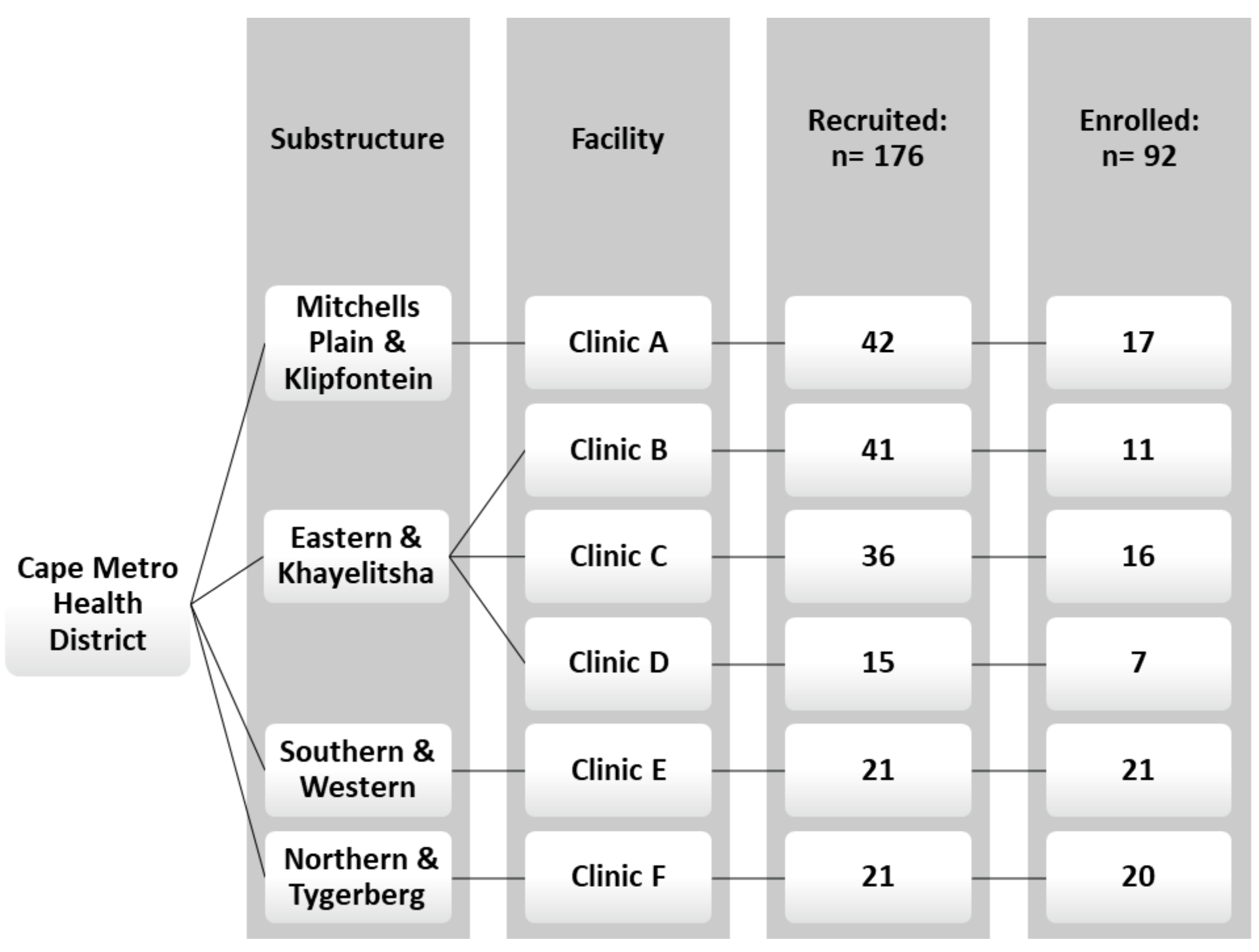

Figure 1

Participant Recruitment and enrolment at respective facilities 


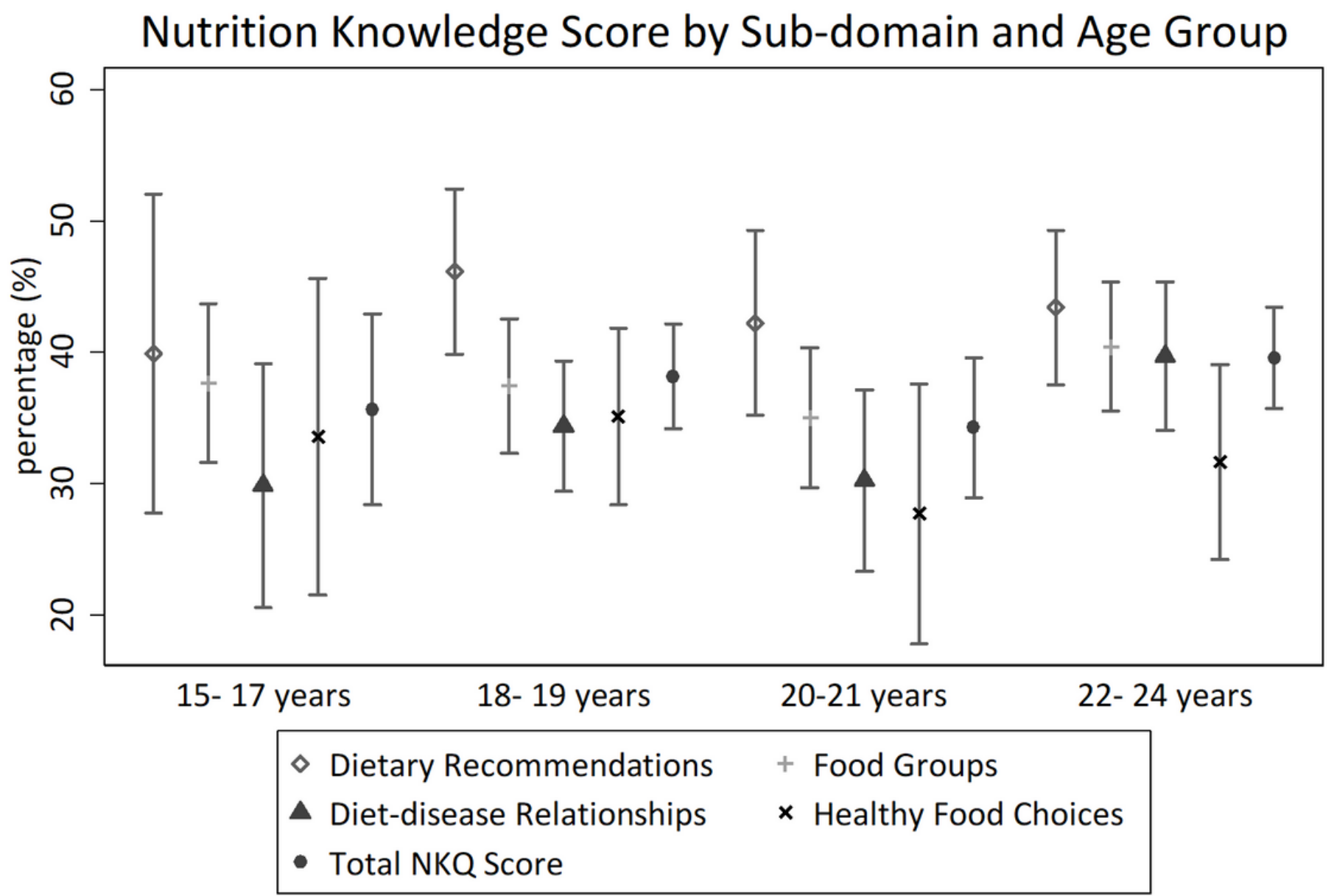

$95 \%$ confidence intervals

Figure 2

Nutrition Knowledge Score by Sub-domain and Age Group 
Risk Behaviours by Gender and Age

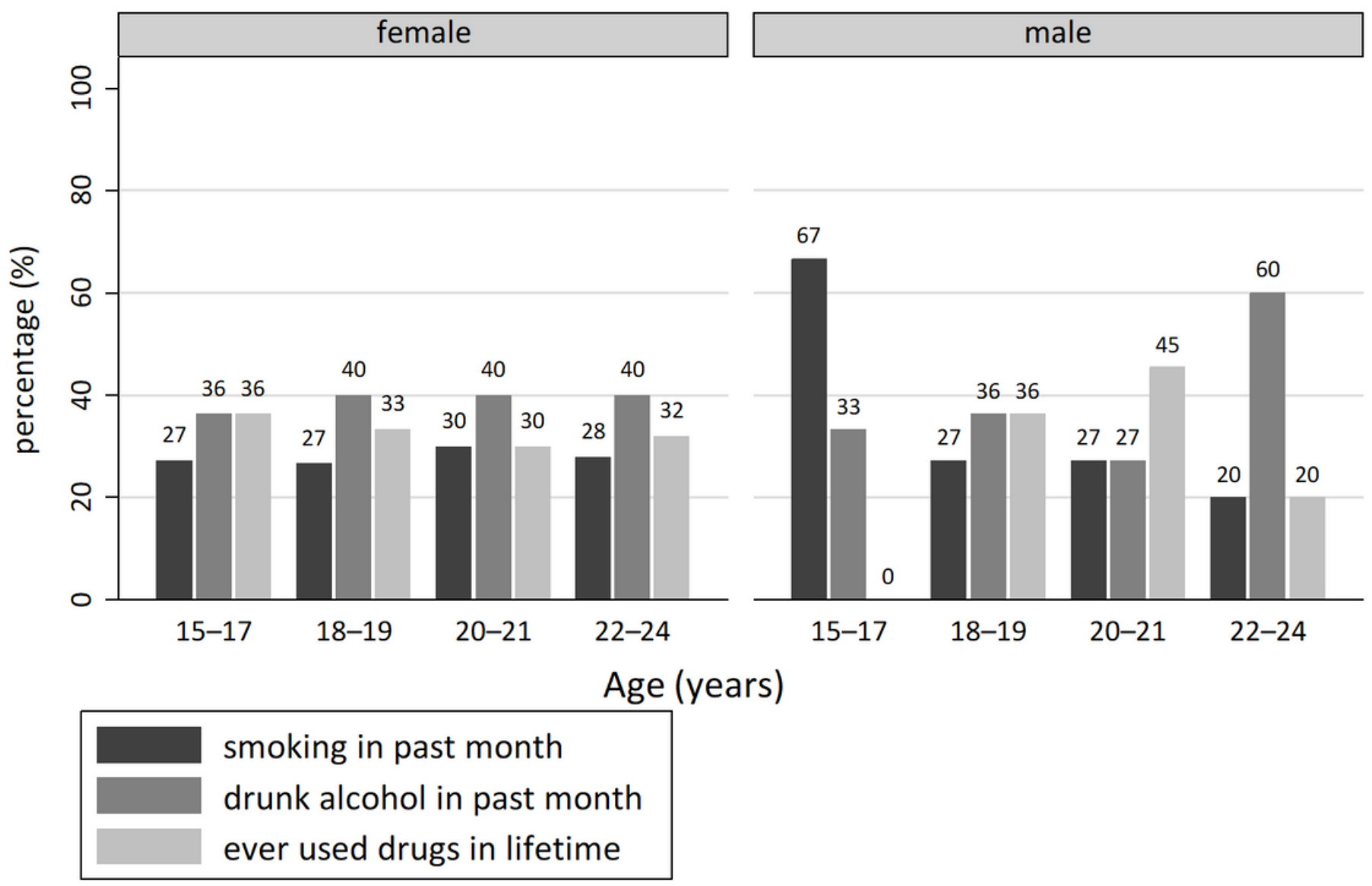

Figure 3

Current smoking, alcohol consumption, and lifetime substance use by Gender and Age Group 


\section{CESD-10 Depression by Gender and Age}

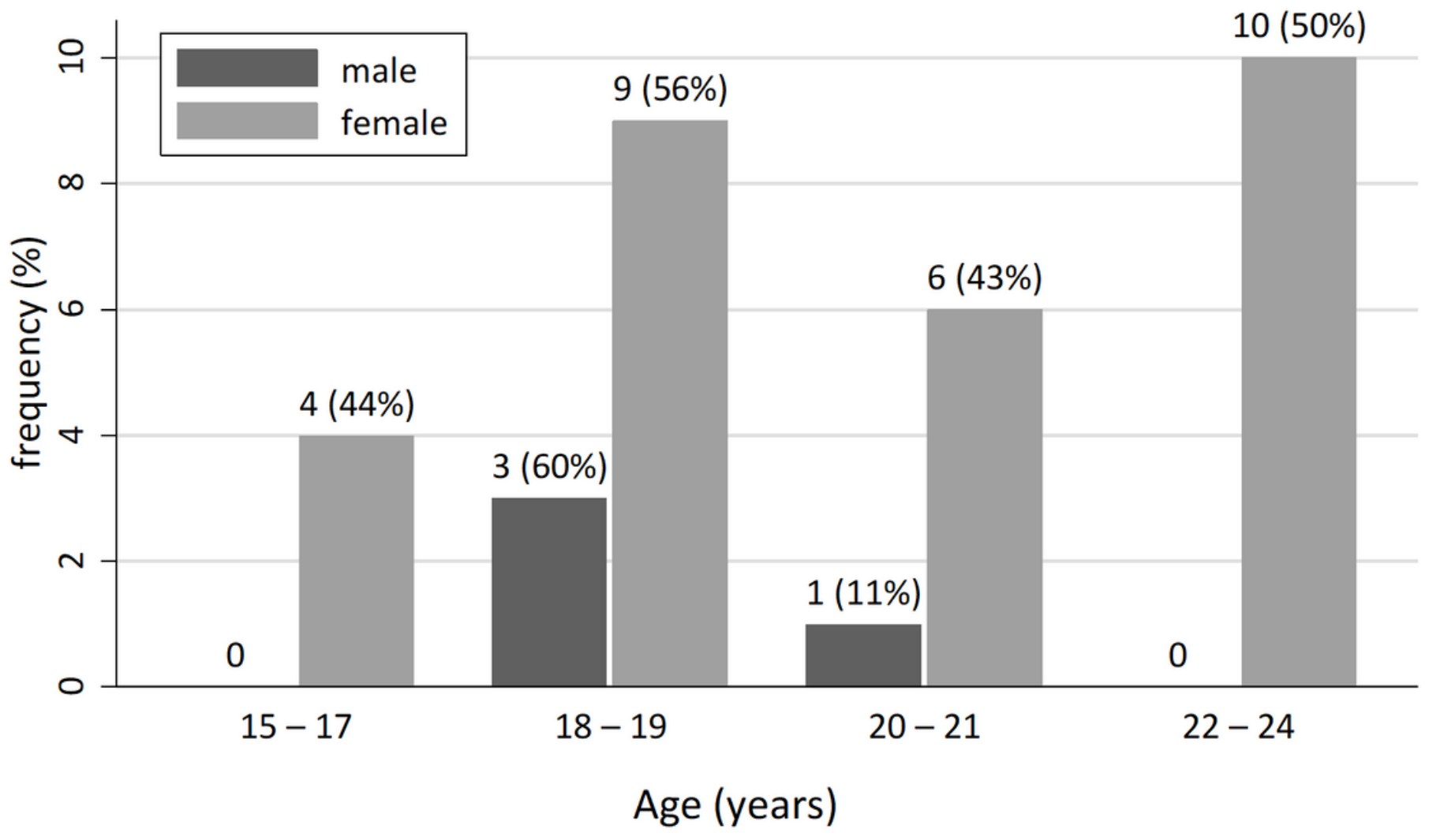

Figure 4

Mental Health Status by Gender and Age Group Bar represents proportion (\%) with significant depression (CESD score $\geq 10$ ) by gender in each age group. 


\section{Psychological Distress by Gender and Age}

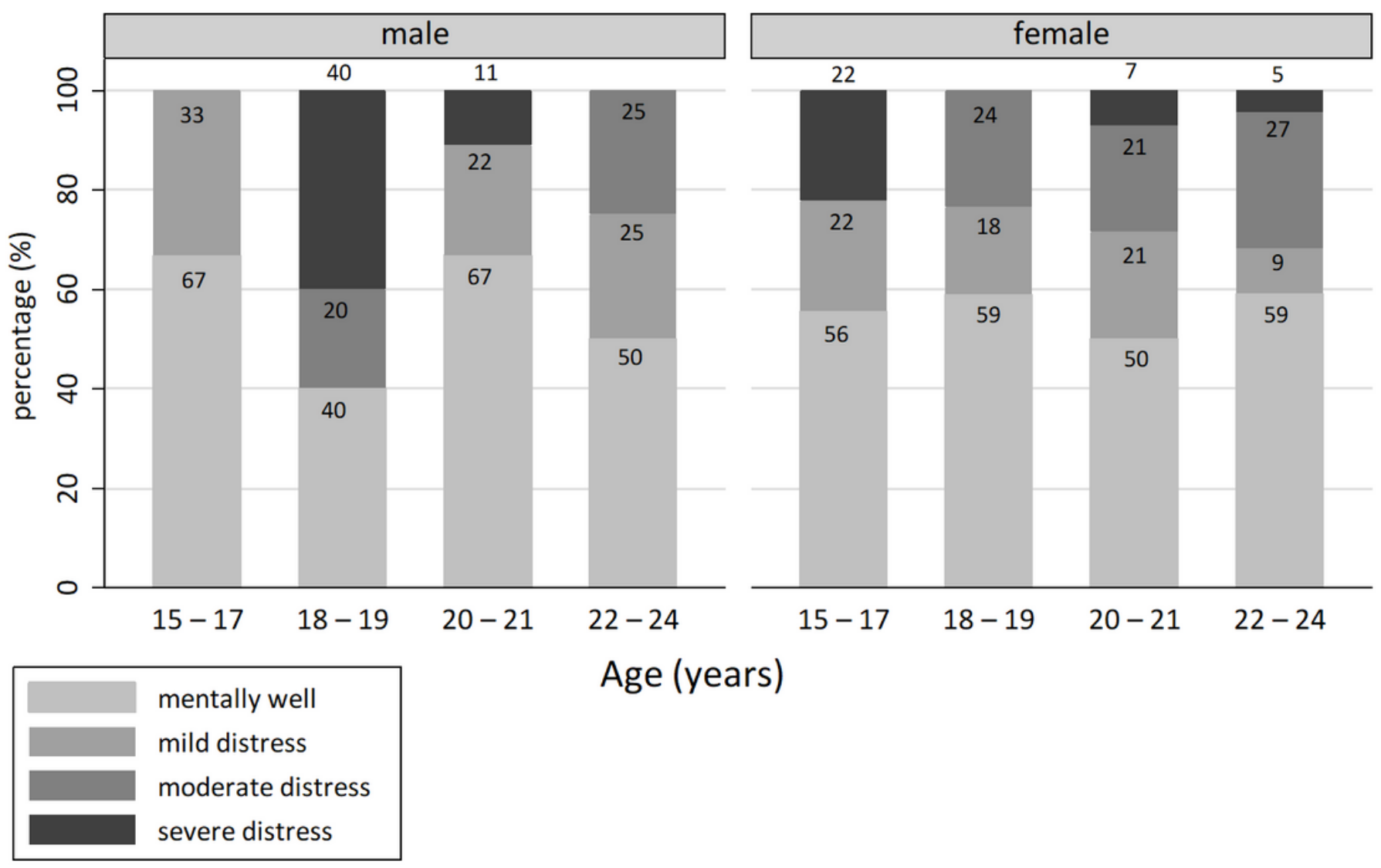

Figure 5

Severity of Psychological Distress by Gender and Age Group Psychological distress according to Kessler (K10) Distress Scale. Bars represent severity of distress (\%) by gender and age group 


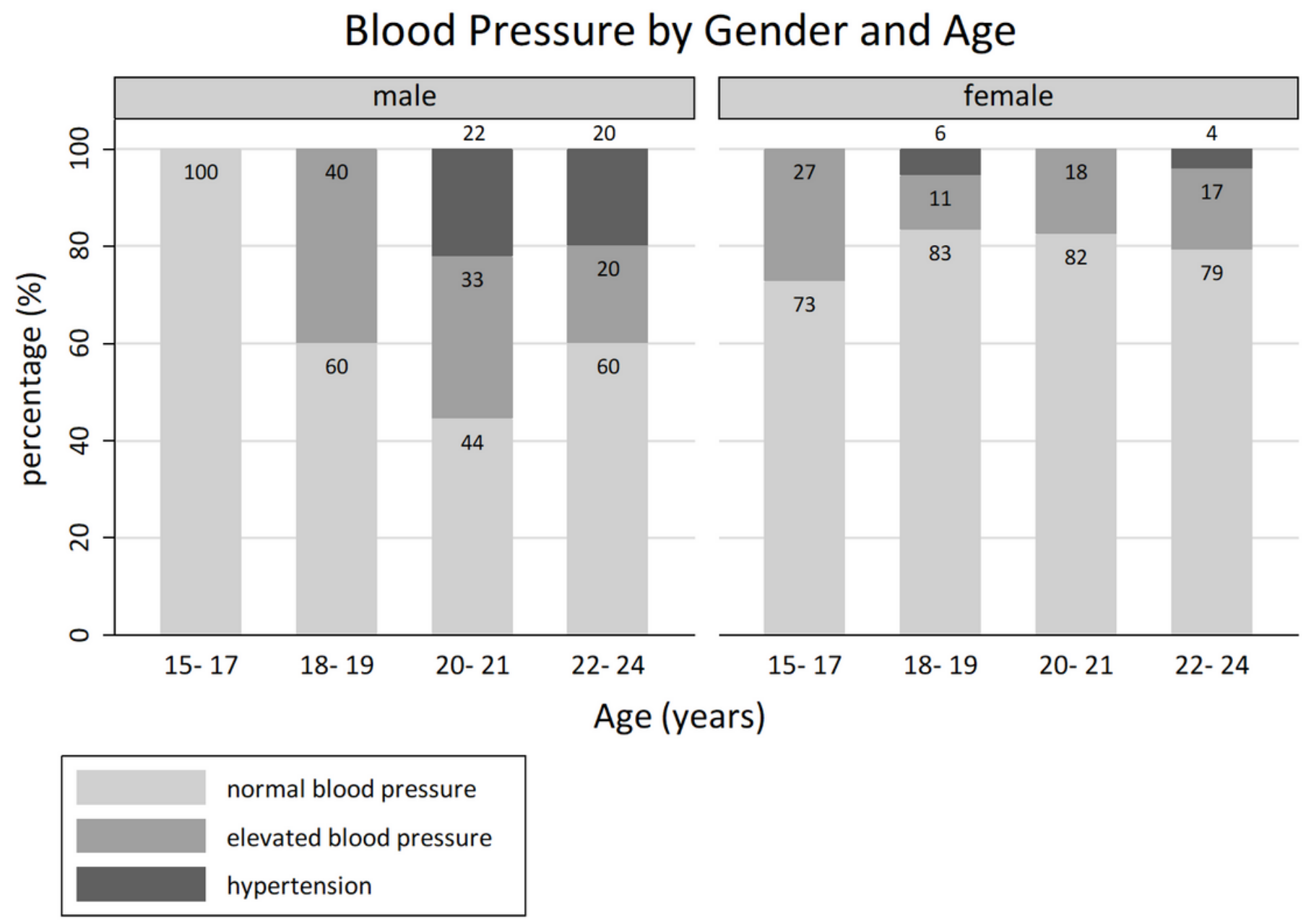

Figure 6

Blood Pressure Category by Gender and Age Group 


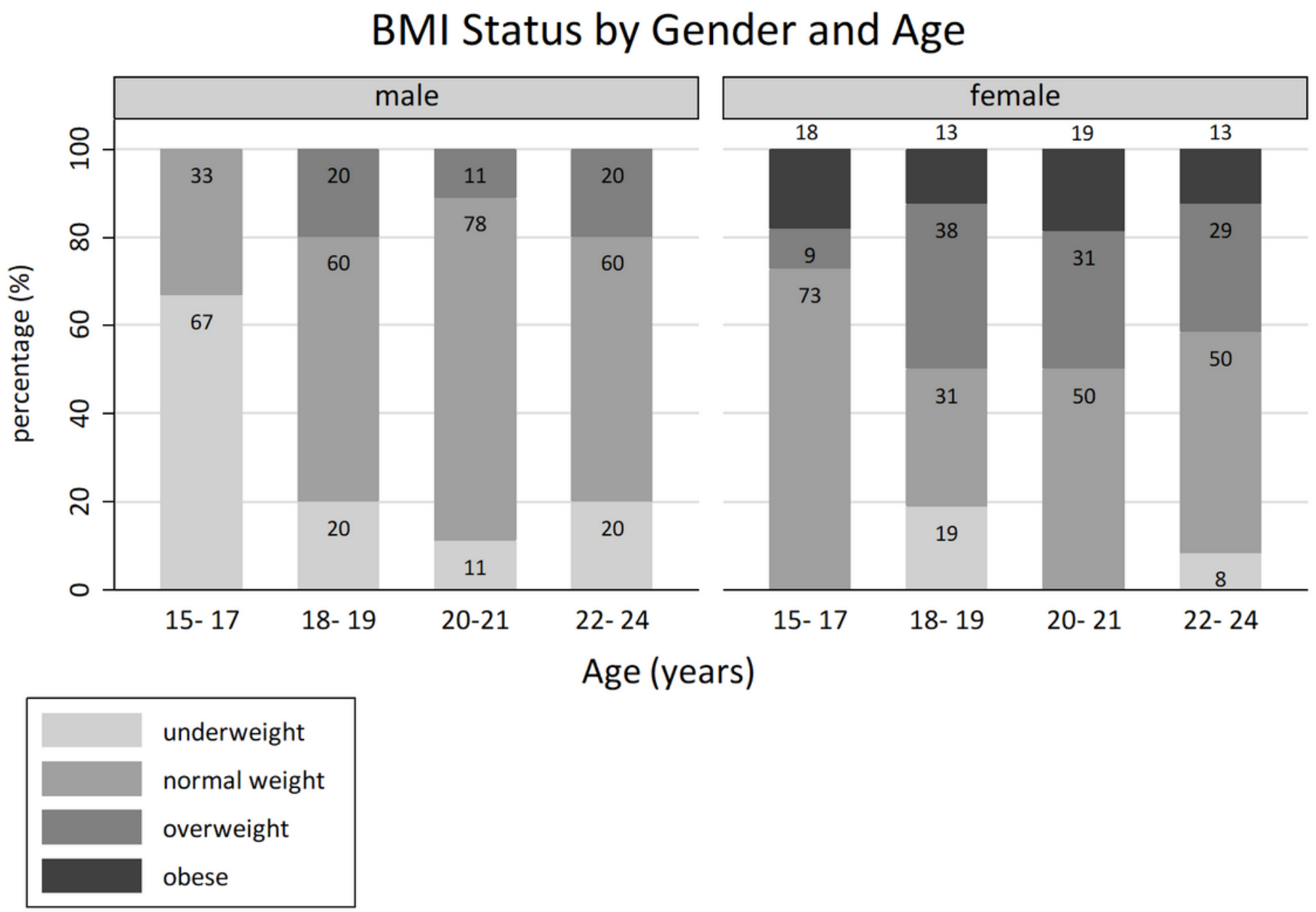

Figure 7

Weight Status by Gender and Age Group 